\title{
Commercial Relations Between Brazil and India: An Analysis of Trade Chain and the Challenger for the Coming Years
}

\author{
Alessandro da Silva Nunes ${ }^{1}$, Tuany Esthefany Barcellos de Carvalho Silva ${ }^{2}$, Tayla Jamylle Martins Bonfá Frias ${ }^{1} \&$ \\ Daiane Rodrigues dos Santos ${ }^{1}$ \\ ${ }^{1}$ Universidade Veiga De Almeida, Brazil \\ ${ }^{2}$ Universidade Federal Fluminense, Brazil \\ Correspondence: Daiane Rodrigues dos Santos, UNIVERSIDADE VEIGA DE ALMEIDA E UNIVERSIDADE \\ CANDIDO MENDES, Brazil. E-mail: daianesantoseco@gmail.com
}

Received: July 10, 2020 Accepted: August 13,2020 Online Published: August 19, 2020

doi:10.5539/jms.v10n2p24 URL: https://doi.org/10.5539/jms.v10n2p24

\begin{abstract}
Brazil and India are distinct countries in many fields such as culture, politics and religion, but some similar characteristics are noted. When it comes to territorial extension and population, the two countries are classified as emerging and are currently members of the BRICS Summit. The proximity of countries has become evident in the 21 st century, where they seek to achieve the same goal, a greater participation in the world order. The trade relationship between them aims at positive impacts on both economies. This paper seeks to present the characteristics of the Brazil-India trade relationship and its implications for Brazil. Part of the scope of this research was the study of the relationship between the Brazil-India Trade Chain and some macroeconomic variables of these countries, for that a nonlinear causality test was applied, and the Factorial Analysis (main components) was also used. Finally, three methodologies were applied to model and forecast the Trade Chain (cross-validated LASSO, Neural Networks and non-tuned Random Forest) and a comparison was made between the metric performances, thus generating a satisfactory result, where was it noted that India presents a growing share of its trade balance on the GDP, which makes this market attractive to Brazil, because there is a significant increase in commercial relations.
\end{abstract}

Keywords: Brazil, India, economy, trade balance, machine learning, cross-validation and factorial analysis

\section{Introduction}

Brazil's political history in recent decades has given the country a scenario of economic instability that has persisted over the years. A consequence of this was the low confidence of external investors, which makes international negotiations difficult. However, the last two decades have been marked by a series of liberalist actions which, despite the permanent political instability, have increased international trade relations. Currently, according to the World Bank (2019), Brazil occupies the position of ninth largest economy in the world. India has a colonialist past, like Brazil, which influenced the formation of its economy. Today India is the second most populous country in the world and is expected to reach first place as early as 2025 (World Bank). In the current economic scenario, India has presented characteristics that provide for an increasingly participatory future in the world economy. An important indicator that affirms its macroeconomic efforts is the GDP, becoming the seventh largest in the world according to economic data from the World Bank (2019).

This article aims to study trade relations between Brazil and India, as this has proven to be a promising alliance for both in the coming years. As in China, India's increasing production capacity offers a great opportunity for Brazil to grow as an exporter of raw materials and basic supplies (Agência Brasileira de Promoção de Exportações e Investimentos-APEX, 2012). This bilateral relationship shows that the two countries are not competitors but allies for mutual growth.

Brazil and India form together with Russia, China and South Africa the group entitled BRICS, characterized by emerging economies in countries with large geographic and demographic dimensions and that currently have influence in the world economy and show great potential for growth through trade alliances (Araujo JR \& Costa, 2010). Some peculiarities in the economies of these countries are responsible for the attention they have received. One of the most evident indicators is demographic, since these countries accounted for $41.8 \%$ of the world 
population in 2018, according to United Nations data (2019). As for international trade relations, the BRICS had an increase from 7.7\% to 18\% in the sum of world exports between 2010 and 2017, according to the Institute of Applied Economic Research (Instituto de Pesquisa Econômica Aplicada-IPEA, 2018), showing the potential for economic growth in the world scenario.

The GDP of the BRICS has had a great influence on the world scene. In 2018 they were responsible for $23.5 \%$ of the world GDP, according to data from the World Bank. Due to the history of trade relations between these countries, the forecasts of population growth of the young working mass, the import of manufactured goods by India and of basic and semi-finished products by Brazil, should not ignore the potential of future alliances with incentive to bilateral trade.

This work aims to highlight the characteristics of the Brazil-India trade relationship and its impacts on the global scenario. It seeks to analyze the effects on the Trade Chain and macroeconomic variables, to perceive economic changes in both countries, present possibilities and trends of this market. It is part of the scope of this research the application of non-linear causality test and Factorial Analysis (main components) for the study of the relationship between the Brazil-India Trade Chain and some macroeconomic variables of these countries. Finally, this study applied three methodologies for modeling and forecasting the Trade Chain (cross-validated LASSO, Neural Networks and non-tuned Random Forest) and carried out a comparison between the metric performances.

Section 2 will present the bibliographic review of this paper, subsections 2.1 and 2.2 being devoted to the main characteristics and economic activities of Brazil and India, respectively. Subsection 2.3 discusses trade relations between the BRICS and how this group presents itself as an important economic denominator, while section 2.4 presents the direct relationship between Brazil and India in the economic context. In section 3 the methodology used in the present work will be presented, being divided between the analysis of the Trade Chain between the two countries, the Factorial Analysis using the technique of analysis of main components, and the studies performed with machine learning using three models for the prediction of the Trade Chain: cross-validated LASSO, neural networks and non-tuned Random Forest. Finally, the results obtained with the studies will be highlighted, followed by the conclusion of the work.

\section{Bibliographical Review}

\subsection{Brazil's Main Economic Characteristics and Activities in Recent Years}

According to Haffner and Monteiro (2011), Brazil still has economic characteristics that demonstrate how harmful exploratory colonialism has been in its history. Nevertheless, it is considered the main South American regional power.

In recent years Brazil has experienced economic instability as a result of divergent political scenarios. Over the last 20 years there has been a collection of successes and failures, having achieved since important agreements with economic blocs, an increase in the growth rate of GDP (Gross Domestic Product) and the HDI (Human Development Index), even cases of fraud and corruption, making the country's environment confused, and thus driving away the interests of foreign capital inflow. For many years, especially as of the 1960s, the country went through a wave of industrialization, which brought a permanent return of great importance to the current economy. However, since the 90 's, Brazil has turned to the external market taking the position of raw material exporter country.

According to the International Monetary Fund (2019), Brazil is currently the ninth largest global economy, in 2014 it was in seventh place. This loss of position was due to a political crisis that was instituted through cases of corruption by government members. This year, for Niewierowski (2016), Brazil was the country that presented the biggest reduction in exports among the main economies, mainly due to the drop in commodity prices, reaching three positions in the world export ranking, from 22nd to 25th. As a result of this scenario, the number of exporting companies fell and the number of importers grew. And, as can be observed in Figure 1, the years 1996 and 2014 presented the largest deficit records in the trade balance, already 2017 shows a surplus of US\$ 1.9 billion relative to the previous year. 


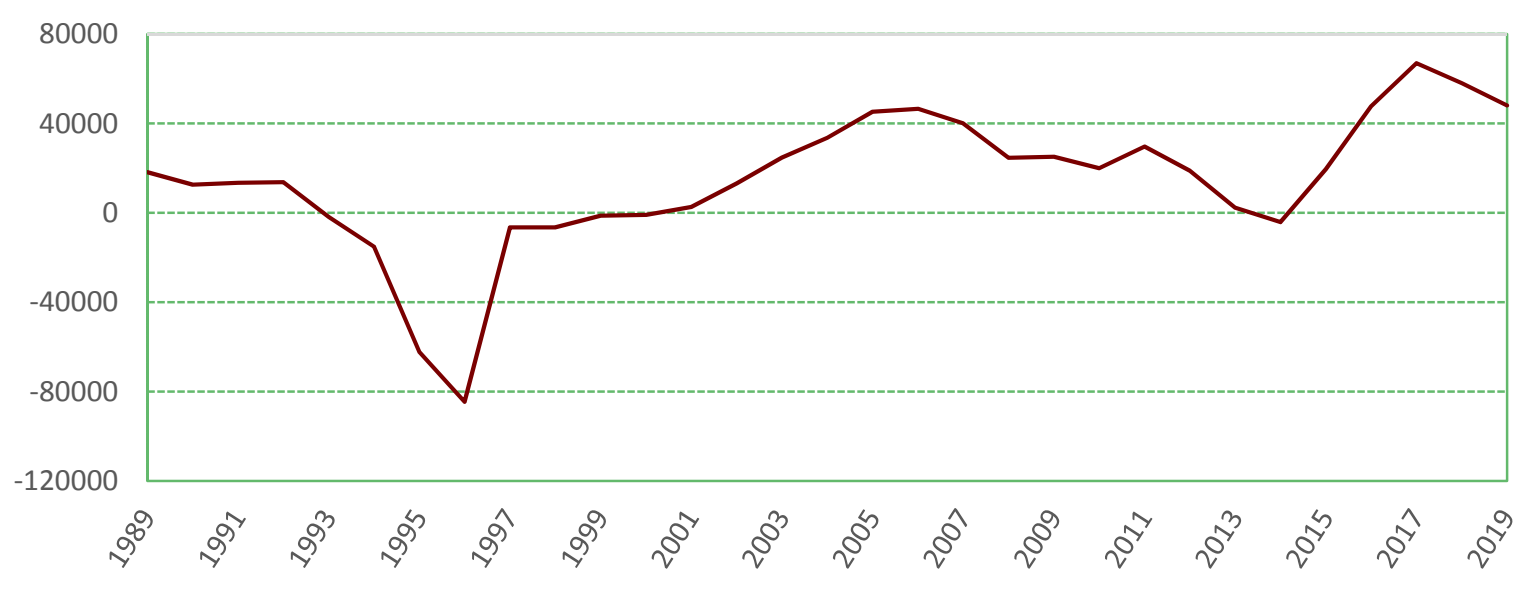

Figure 1. Brazilian trade balance

Source: Own preparation based on MDIC data.

After a drastic recession in 2015-2016, 2017 was a milestone, when there was an annual growth of 1\% in GDP. Optimistic perspectives were incited from what happened, but in the following years, 2018 and 2019, the growth rate did not exceed $1.6 \%$, with short variations, contrary to expectations, which were of a growth of $2.5 \%$ in 2018, observed in Figure 2.

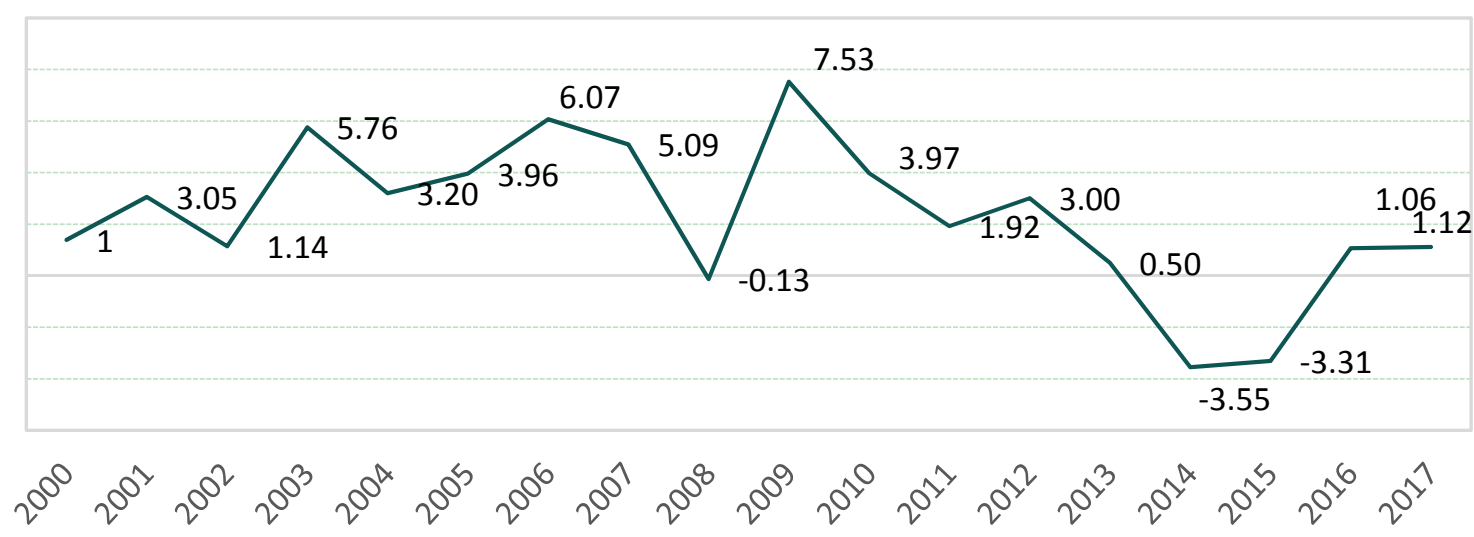

Figure 2. Brazil's annual GDP growth rate

Source: Own preparation based on IBGE data, 2019.

With projections until 2023, Brazil shows growth conditions of around $2.5 \%$, without the emergence of higher inflationary pressures (Tinoco \& Giambiagi, 2018). Currently, the country is in the process of government reformulation, and there are still uncertainties as to its course, which generate various speculations by investors. However, the characteristics of the current economic scenario have presented the objective of making it more inviting, with less bureaucracy for foreign investors and lower rates imposed, among other actions that facilitate the entry of foreign capital, thus, consequently, heating up the national economy.

\subsection{India's Main Features and Economic Activities in Recent Years}

The great Indian industrial strategy that leveraged the economy was established soon after its independence in 1947, leading the country into the phase of planned industrialization, at the time the main objective of this technology policy was to internalize technologies, passing them on to the national private sector, causing $R \& D$ to be aimed at creating new local sources of technology (Pianna, 2007).

The Indian economic sector has received a lot of attention worldwide due to its high growth rates in recent years. 
As a great country, India has the second largest nation in the world, with approximately 1.343 billion people in 2019. And according to estimates by the UN Population Division, it is expected to host the world's largest population by 2025 , with 1.4 billion people. The country has the youngest working class in the world, where $60 \%$ of the population is under 24 years old and $80 \%$ under 45 , which makes the workforce a great competitive advantage for its development (Pianna, 2007). Figure 3 shows the GDP of the country in millions of dollars, it can be noticed that there is a significant growth in the series.

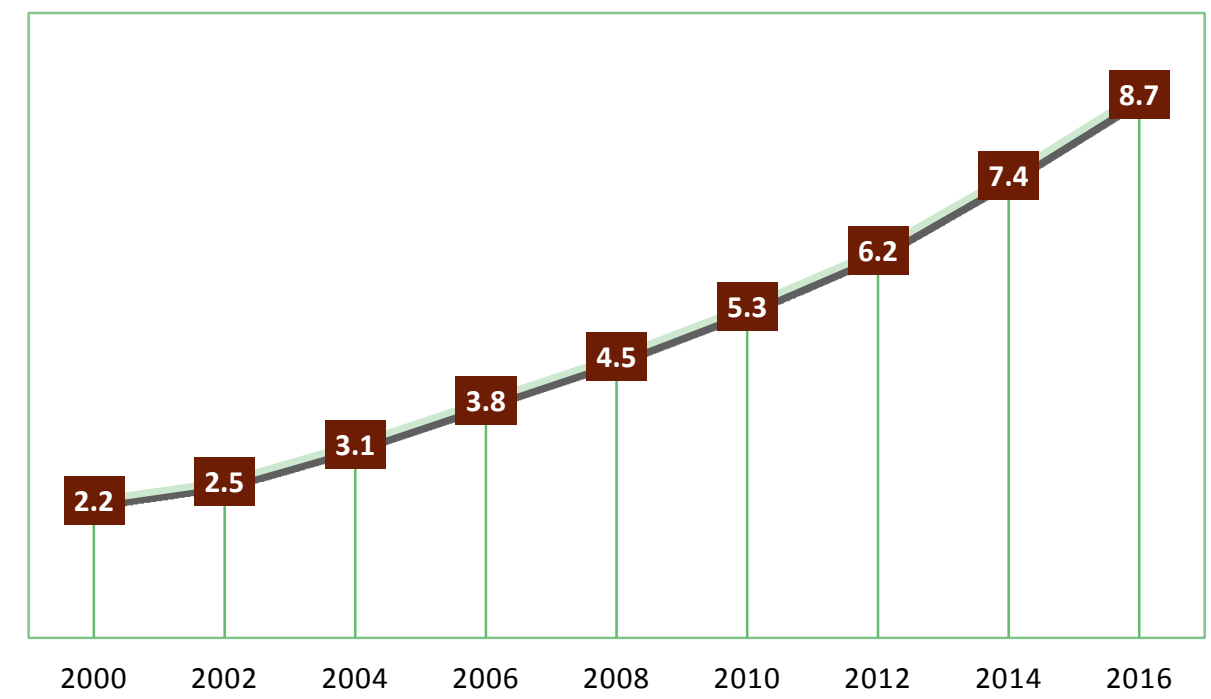

Figure 3. India's GDP in million dollars

Source: Own preparation based on Organisation for Economic Co-operation and Development (OECD) (2020) data, Gross Domestic Product.

According to data presented by the Organization for Economic Cooperation and Development (OECD, 2020), the forecast of Indian GDP for the next 10 years points to constant growth, which is of extreme economic importance. If this forecast materializes it will bring several benefits impacting positively the country. In Figure 4 we can observe this gradual growth, the forecast is based on an evaluation of the economic climate of the country and of the world economy with the values presented in millions of dollars.

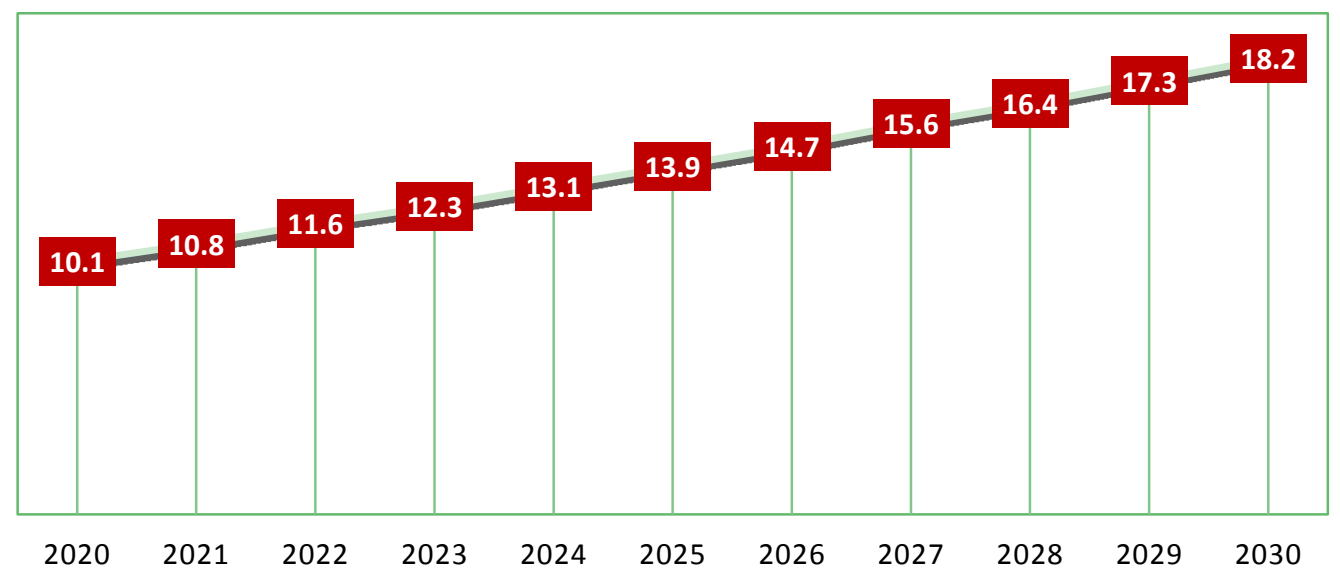

Figure 4. India's GDP forecast in million dollars

Source: Own preparation based on OECD data (2020), Real GDP long-term forecast (indicator). 
Studies by Apexbrasil (2012) suggest that the urbanization process as a major challenge for the Indian government, since only $30 \%$ of the country's inhabitants lived in the urban area in 2010 . In Figure 5 , it is noted that nine years after this period the number increased by approximately $4.5 \%$ only, reaching the mark of $34.5 \%$ in 2019 (Knoema, 2019).

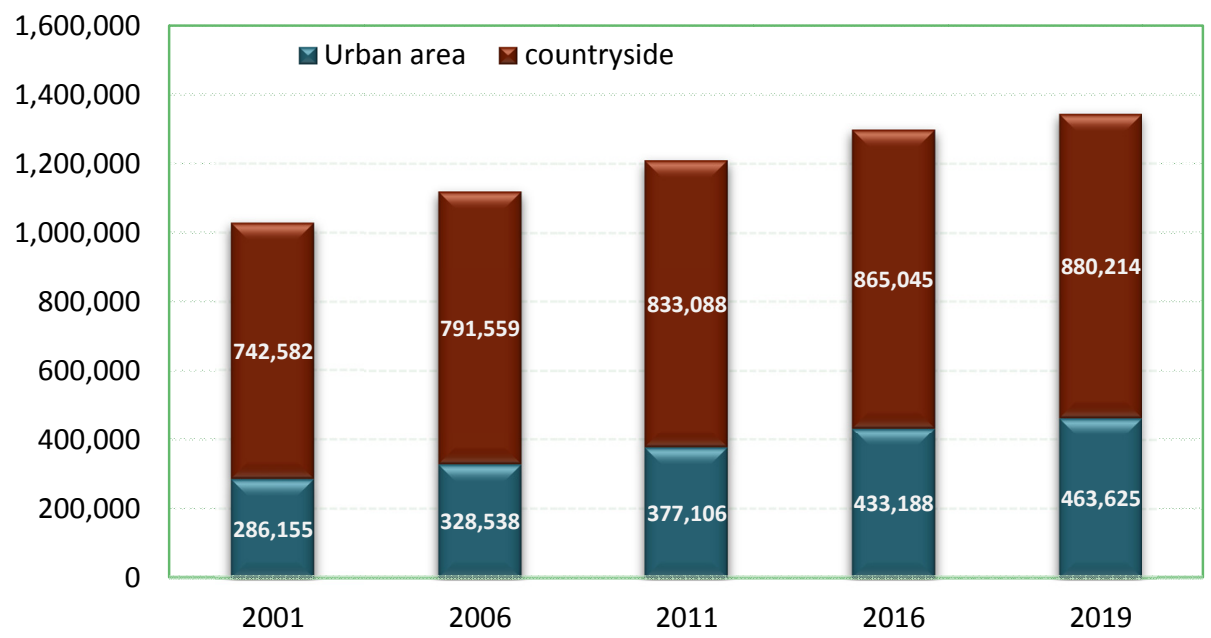

Figure 5. Indian population

Source: Own preparation based on data published by Knoema (2019), in Population Estimates and Projections.

Indian economic growth was led by an efficient productivity response and change strategies of the government in the early 80s, this strategic vision of long-term economic planning favoring the private sector, was the main factor for increasing the growth rate in the period, positively impacting the economy of the country (Pianna, 2007).

\section{BRICS Business Relationship}

BRICS is an expression that was formulated in 2001 by economist Jim O'Neil to name the economic grouping currently composed of five countries: Brazil, Russia, India, China and South Africa. These countries were selected because they were considered to be emerging, with economic potential to surpass the great world powers, over an estimated period of 50 years, and in addition the countries seek to leverage new economic and political configurations with broad and positive repercussions. This merger is not an economic bloc or an international institution, BRICS is an international mechanism formed by an informal grouping. Initially O'Neill (2001) referred exclusively to the first four countries, with emerging economies, large territories and a large population, but the summit opened in 2009 in the Russian city of Ecaterinburg, and South Africa was incorporated into the group after two years, hosting the summit held in Durban in 2013 (Lins, 2019).

It is noticeable that in recent times the international system has been undergoing major changes and the mechanisms of global governance do not represent the current world economic configuration as truthfully. The imbalance of power between the countries of the South and the North is becoming more evident, and so the BRICS strongly aims to reverse this situation by converting its economic influence into a growing political influence (Campos, 2018).

Still according to Campos (2018), the existence of BRICS took place after the main emerging economies showed their dissatisfaction with the actual international order, dominated mainly by the great Western powers. Emerging nations increasingly seek to participate in power, the BRICS Summit believes that together they are stronger to push for reforms in global governance. Figure 6 shows the growing participation of the BRICS economies in world GDP, compared to the European Union and the G7, noting that the forecast for 2020 is that the BRICS participation will also exceed the G7. 


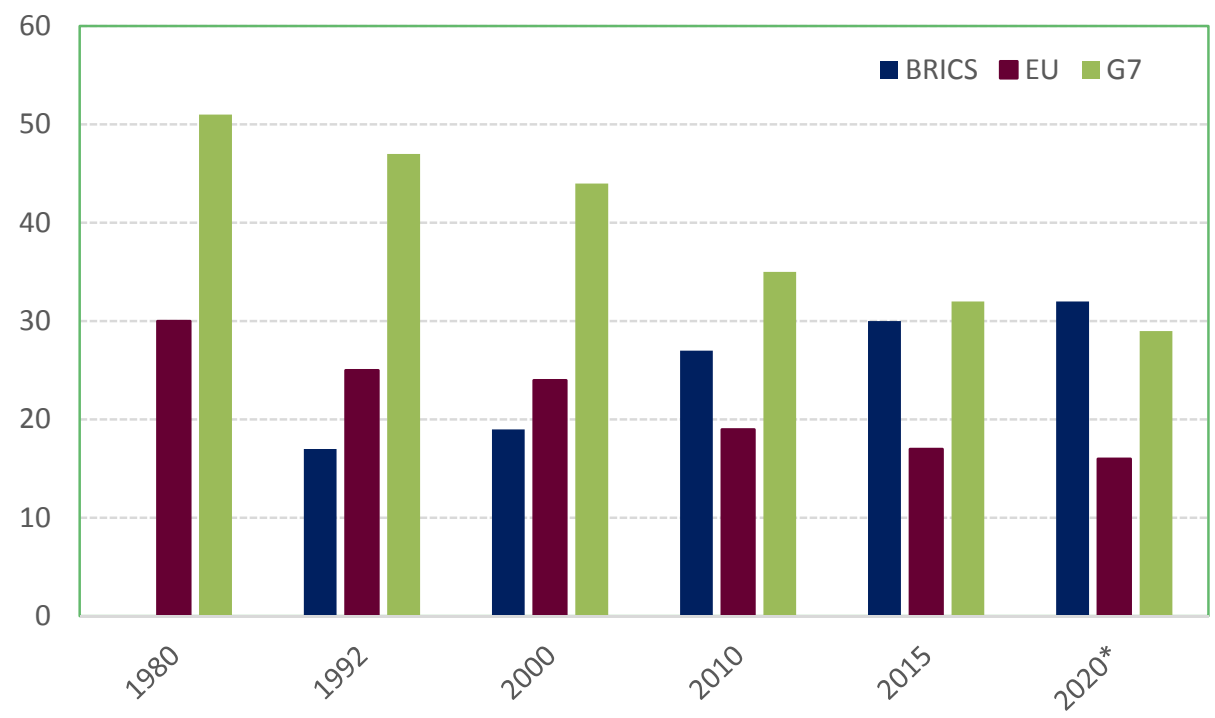

Figure 6. Participation in the world GDP

Source: Own preparation based on Campos (2018), adapted from World Economic Outlook Database.

\subsection{Brazil-India Business Relationship}

This article deals with the commercial relationship between two of the countries forming the economic grouping mentioned above. The reason for the choice was the growth potential of India presented in section 2.2 and the recent past of the benefits brought to Brazil from the growth of China and the strengthening of trade relations between the countries.

The proximity between Brazil and India is increasingly evident, the countries have established an economic relationship that tends to increase. The main objective of this union is to make them more participatory when it comes to the world economy, they are populous countries of great extension with a significant growth potential for the coming years. Brazil and India are different in several areas, but because they are in the category of emerging countries, seeking a better position in the world order, they have established this link in order to leverage the growth of both (Haffner \& Monteiro, 2011).

Brazil and India share similarities and common interests because they are "large peripheral countries", which radically distinguishes them from the middle and small countries of the periphery. Large peripheral countries would be those undeveloped countries, with a large population and a large continuous, non-inhospitable territory, reasonably susceptible to economic exploitation (Guimaraes, 1998, p. 9, own translation) (Note 1).

These countries have carried out significant reforms to develop their industry, seeking positive impacts on the economic sector. Brazil started its reforms before India, but the Asian country started its reform along with the fiscal expansion, putting it in a more favorable position from the 80s. India has joined a reform system with exchange rate devaluation and relaxation in the industrial license, encouraging exports and streamlining import control. Brazil leveraged its reform in the 90 s when it adopted a liberalization policy with faster effects than India's, allowing the country to effectively reduce its tariffs, avoiding high rates such as those sustained by India (Haffner \& Monteiro, 2011).

The reforms implemented by Brazil and India individually have not been effective in reducing barriers to the development of both. Brazil and other underdeveloped countries were unable to have high levels of participation and influence in the world order negotiations, as there was a great strategic discrepancy and different interests in international trade compared to developed countries (Junior, 2012). So, because this problem of the emerging countries, Brazil and India together with other countries seek to reverse this picture into fairer standards for developing nations, focusing on trade flows. In Figure 7 the numbers of Brazilian exports to India by aggregated factor are presented, it is noticed that the largest percentage of exported products are basic products, except for the years 2009 and 2016, where the largest percentage was semi manufactured products. 


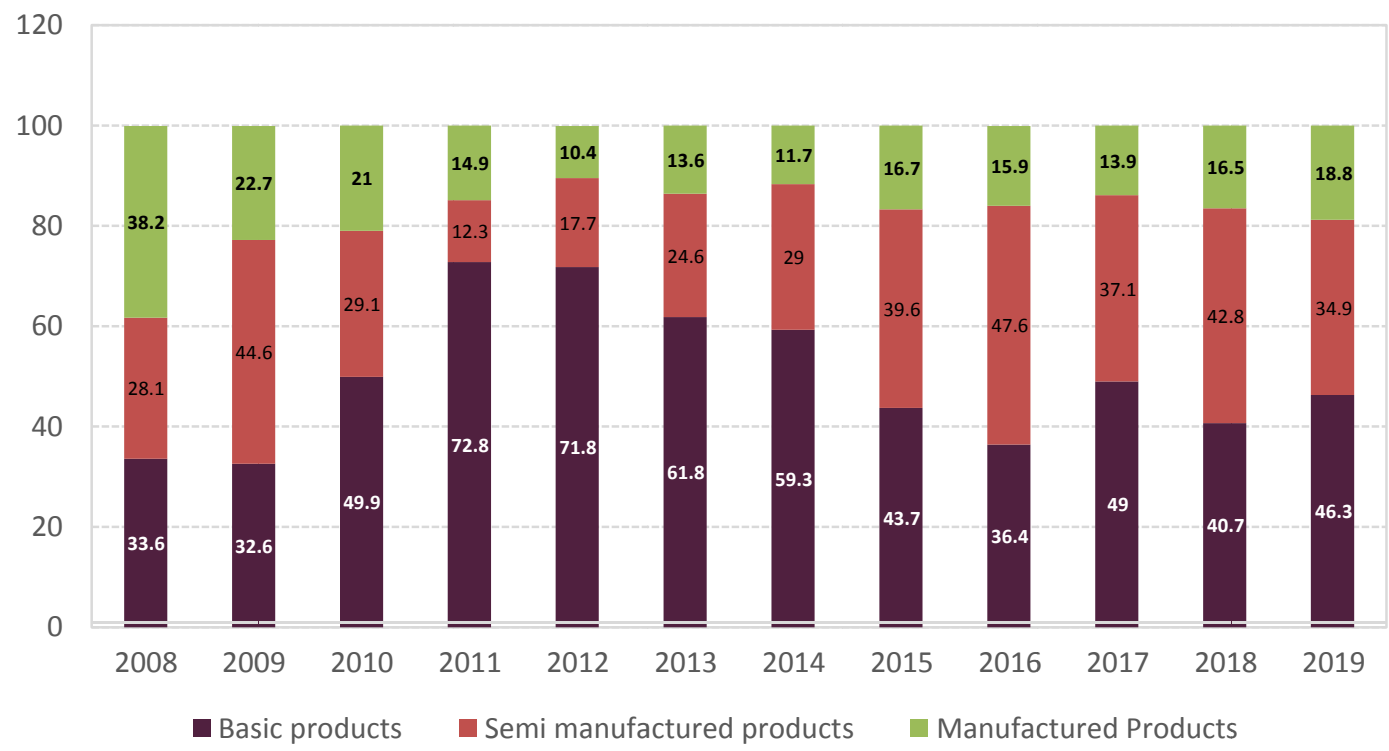

Figure 7. Brazilian exports by Aggregate factor - Partner: India

Source: Own preparation based on data from the Ministry of Economy, Industry, Foreign Trade and Services (MDIC) - Comex Vis: Partner Countries.

In Figure 8 are presented the 20 main products exported by Brazil to India in the year 2019, it is seen that most of the exports are of basic products such as crude oil, crude cotton, ores among others, together they add up approximately $50 \%$ of the products exported Brazil-India.
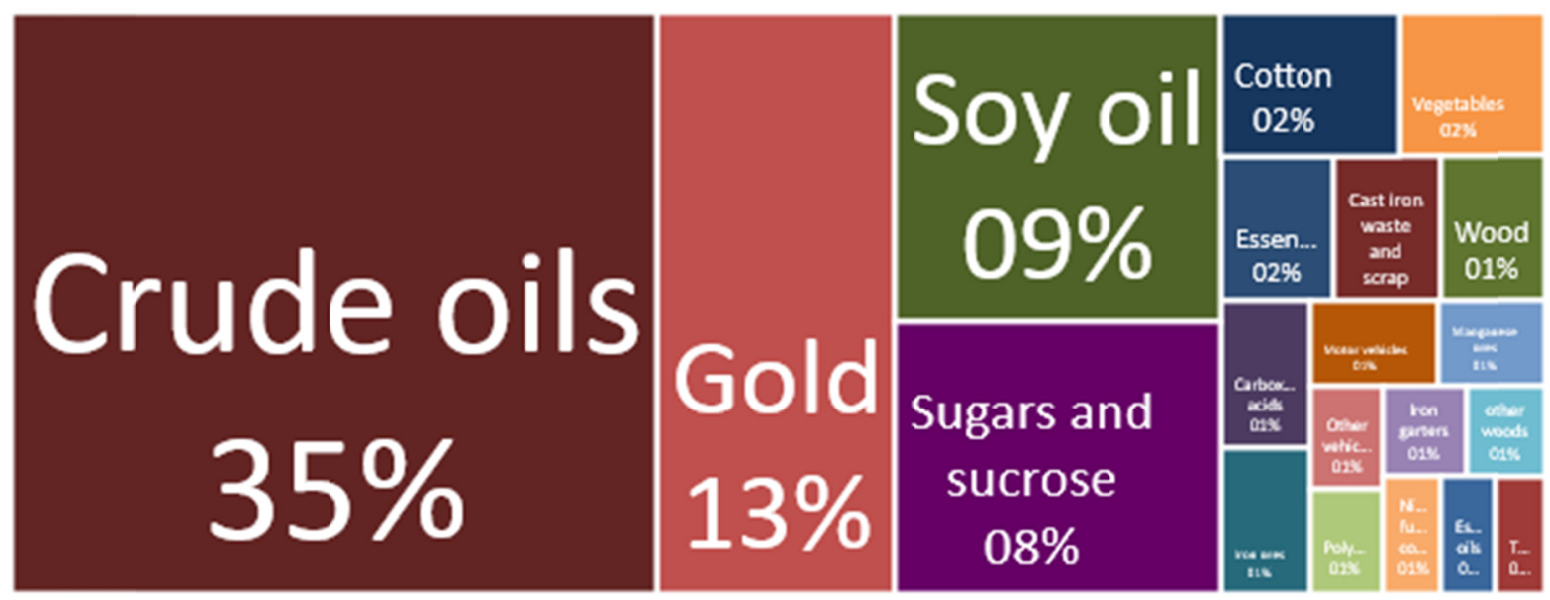

Figure 8. Total exports from Brazil to India - US $\$ 2.8$ billion

Source: Own Preparation based on data provided by the Ministry of Economy Industry, Foreign Trade and Services - Comex.

Figure 9 shows the Brazil-India import numbers by aggregate factor, we notice that there is a high number of manufactured products imports in comparison with the others and this pattern is repeated along the years. 


\section{Basic products $\quad$ Semi manufactured products Manufactured Products}

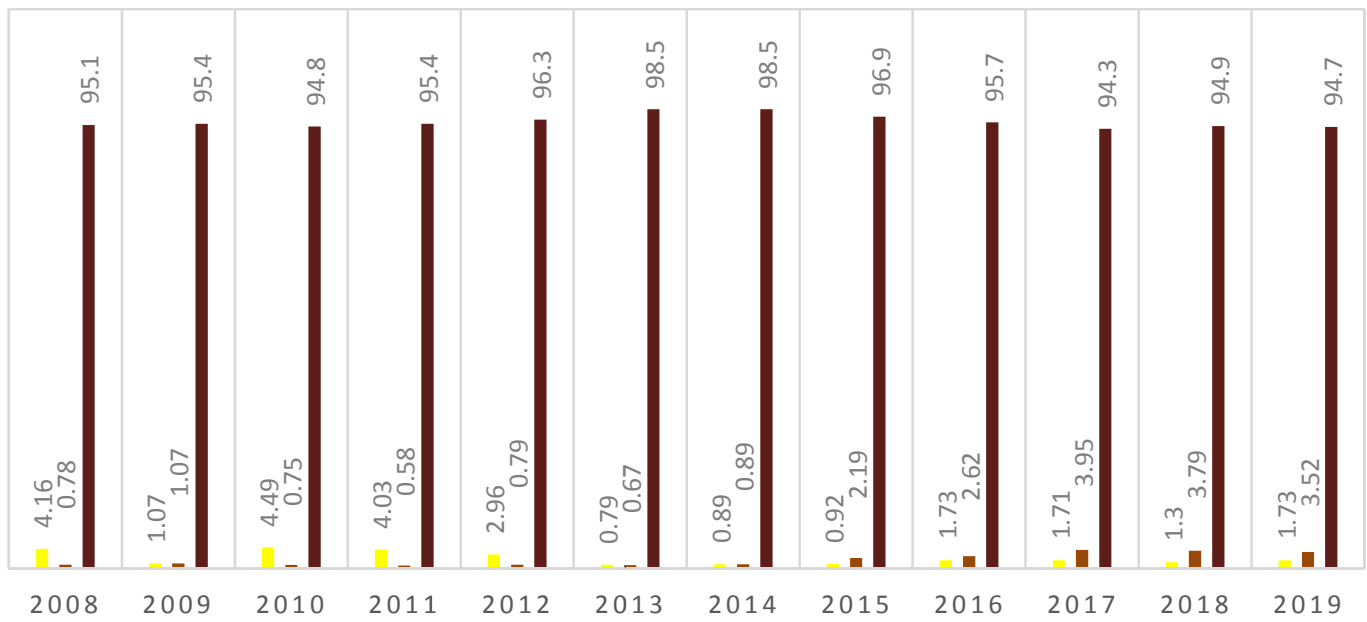

Figure 9. Brazilian imports by Aggregate factor - partner: India

Source: Own preparation based on data from the Ministry of Economy, Industry, Foreign Trade and Services - Comex Vis: Partner Countries.

Figure 10 presents the 20 main products imported from India by Brazil in the year 2019, approximately $66 \%$ of Brazil-India imports are manufactured products.
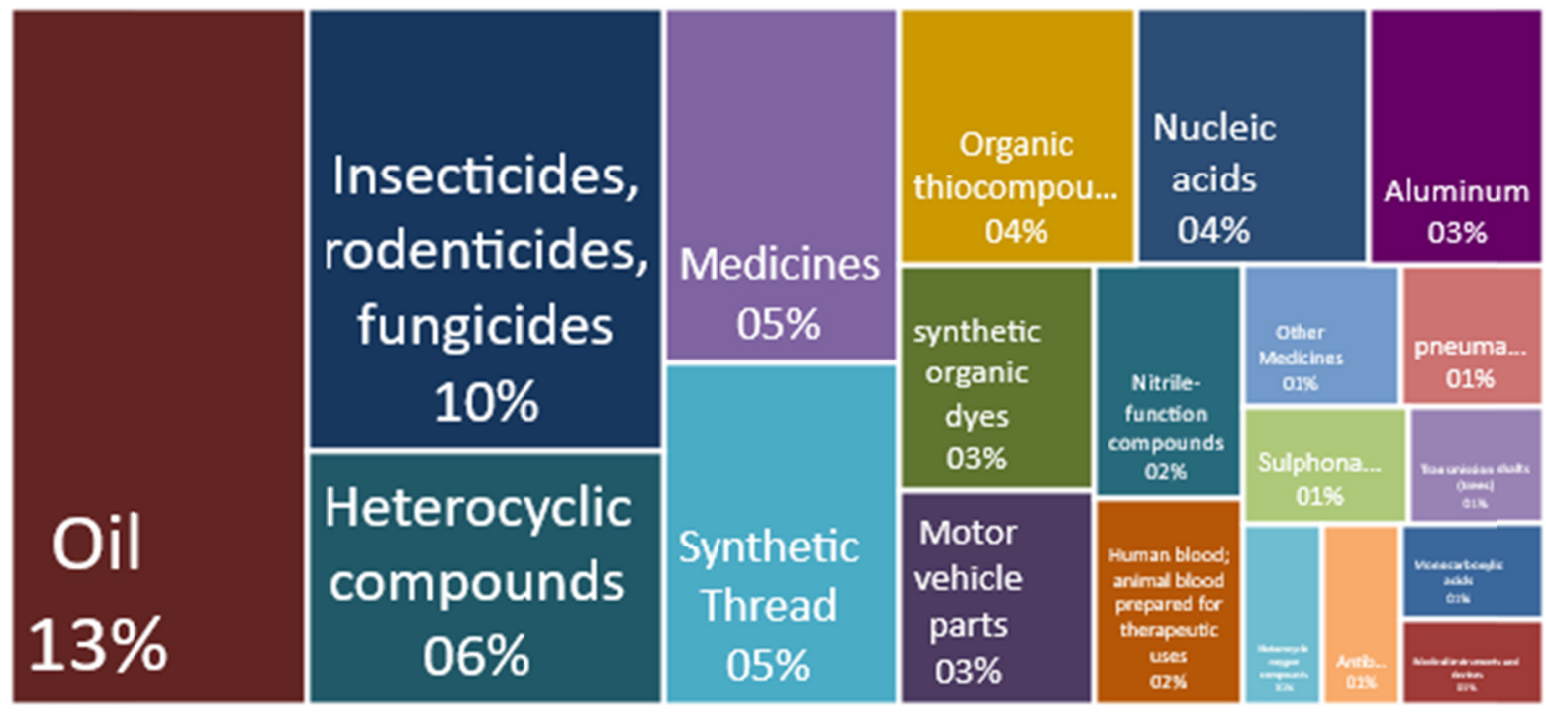

Figure 10. Overview of products imported by Brazil with origin in India - US\$ 4.3 billion

Source: Own Preparation based on data provided by the Ministry of Economy Industry, Foreign Trade and Services - Comex.

\section{Trade Chain Between Brazil and India}

The Trade Chain is defined as the sum of the export and import volumes of a country or region during a given period. It is from this concept that it becomes possible to analyze the intensity of the trade relationship between Brazil and India.

After the beginning of the 2000s the commercial relationship between the two countries narrowed, showing a high level of exports and imports, according to Figure 11. Imports from India reached US\$6.64 billion in 2014, while exports reached US\$5.57 billion in 2012. 


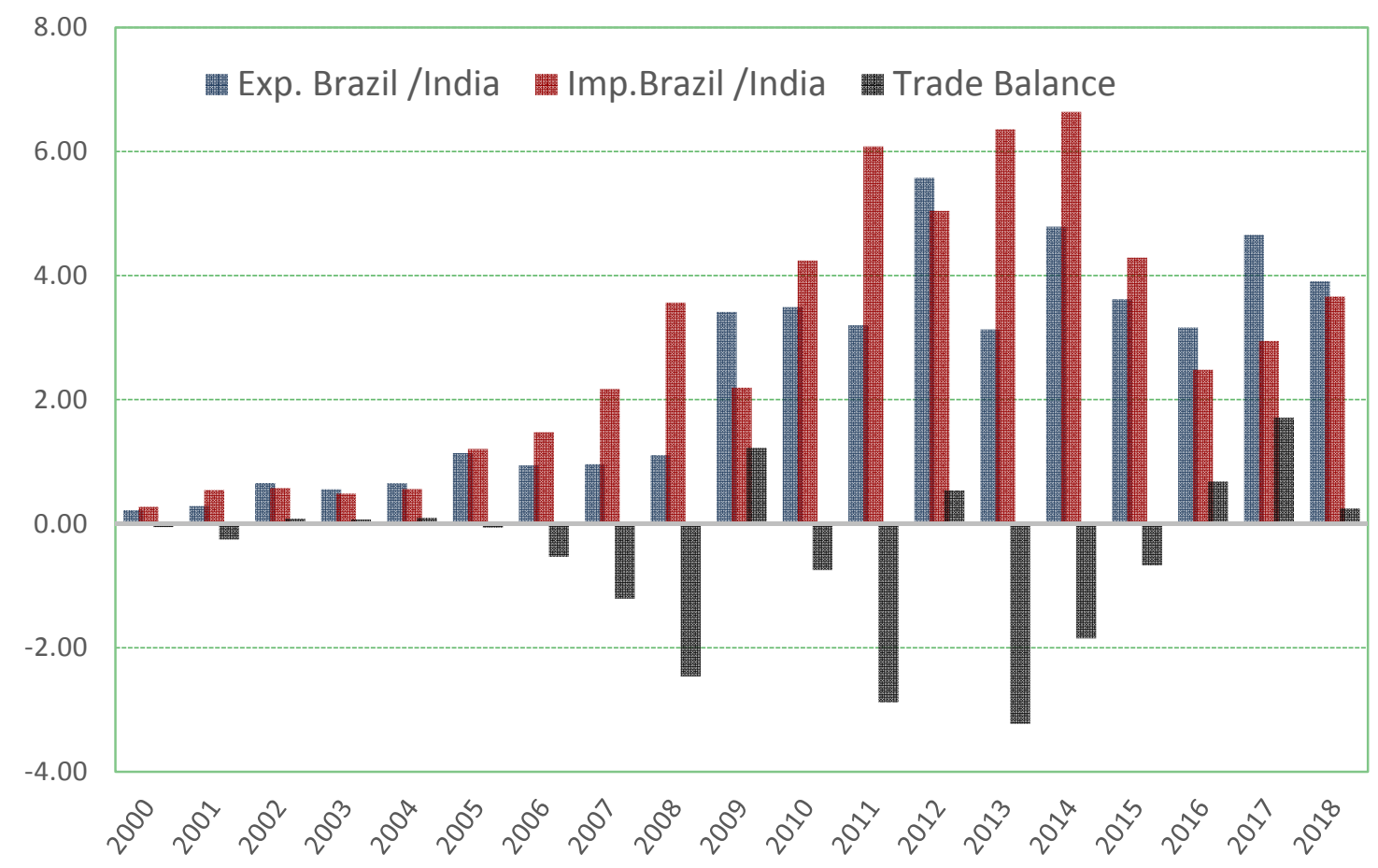

Figure 11. Brazil-India trade balance in US\$ million (2004-2018)

Source: Own preparation based on data from the Ministry of Economy, Industry, Foreign Trade and Services - Comex Vis: Partner Countries. 2019 .

From this intensification in trade between the two countries and India's potential growth in both population and GDP, it is believed that the increasingly intense trade alliance can be highly beneficial on a bilateral basis. To support this argument, an analysis of the trade factor under the economy of Brazil and India, and how trade between the countries influences the Brazilian economy, was conducted. The results were used to verify the premises that led to the development of this study.

When dealing with Trade Chain data, it is important to note that the study of the data presented here follows the methodology of classification by value added. Brazil adopts this methodology to carry out studies related to import and export, according to SECEX.

For the analysis of the Brazil-India Trade Chain, data for the last two decades (2000-2019) will be the object of analysis collected in the database of the Ministry of Development, Industry and Foreign Trade (MDIC). In Table 1 are presented the import and export data and the due Trade Chain, that is, the sum of them. Therefore, it can be observed that bilateral trade between Brazil and India has been increasing along the years. 
Table 1. Historical export, import and trade balance data in US\$ Millions

\begin{tabular}{llll}
\hline Year & Import & Export & Trade Chain \\
\hline 2000 & 272 & 217 & 489 \\
2001 & 542 & 285 & 827 \\
2002 & 573 & 654 & 1.227 \\
2003 & 485 & 553 & 1.039 \\
2004 & 556 & 651 & 1.207 \\
2005 & 1.203 & 1.138 & 2.340 \\
2006 & 1.472 & 939 & 2.411 \\
2007 & 2.139 & 958 & 3.097 \\
2008 & 3.558 & 1.102 & 4.660 \\
2009 & 2.191 & 3.414 & 5.606 \\
2010 & 4.243 & 3.490 & 7.734 \\
2011 & 6.078 & 3.200 & 9.279 \\
2012 & 5.043 & 5.576 & 10.618 \\
2013 & 6.357 & 3.130 & 9.487 \\
2014 & 6.640 & 4.788 & 11.428 \\
2015 & 4.289 & 3.617 & 7.907 \\
2016 & 2.482 & 3.161 & 5.644 \\
2017 & 2.946 & 4.657 & 7.603 \\
2018 & 3.663 & 3.909 & 7.572 \\
2019 & 4.258 & 2.777 & 7.034 \\
\hline
\end{tabular}

Source: Own preparation based on MDIC data.

Although the end of the last decade has signaled a decrease in the Brazil-India Trade Chain. Only in 2016 was its result considerably lower than the other years in the period in question. In addition, there have been positive impacts on the GDP of both countries, especially in India, which has been growing steadily without significant decreases since 2004. Brazil's GDP, on the other hand, suffered some oscillations; in 2013 it showed a slight fall. Comparing the GDP (Figure 12) and the Trade Chain (Table 1) it can be observed that the GDP decrease occurred in the same year when the Chain presented the largest value among the analyzed years. Consequently, in the following year it was registered the largest import volume from Brazil in this bilateral relationship.

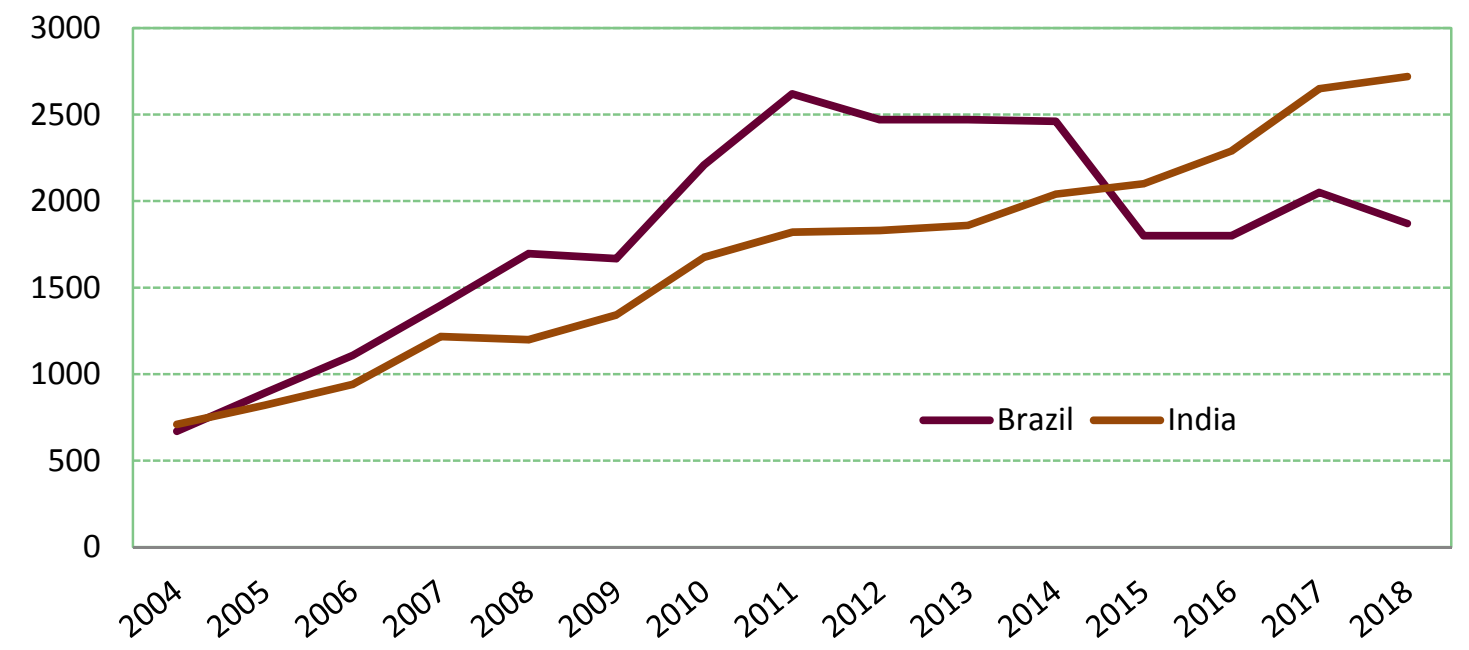

Figure 12. Comparative GDP between Brazil and India (2004-2018)

Source: Own preparation based on World Bank data, 2019.

In Figure 13 it can be observed the intensity of international trade in the economy of each country. It is calculated by adding exports and imports of goods and services (Trade Chain) measured as a share of the GDP. Therefore, the proportion of the Trade Chain in the GDP is calculated. As can be seen, from the 90's this proportion increased considerably in both countries, however, in India this growth showed an exponential trend 
until 2012.

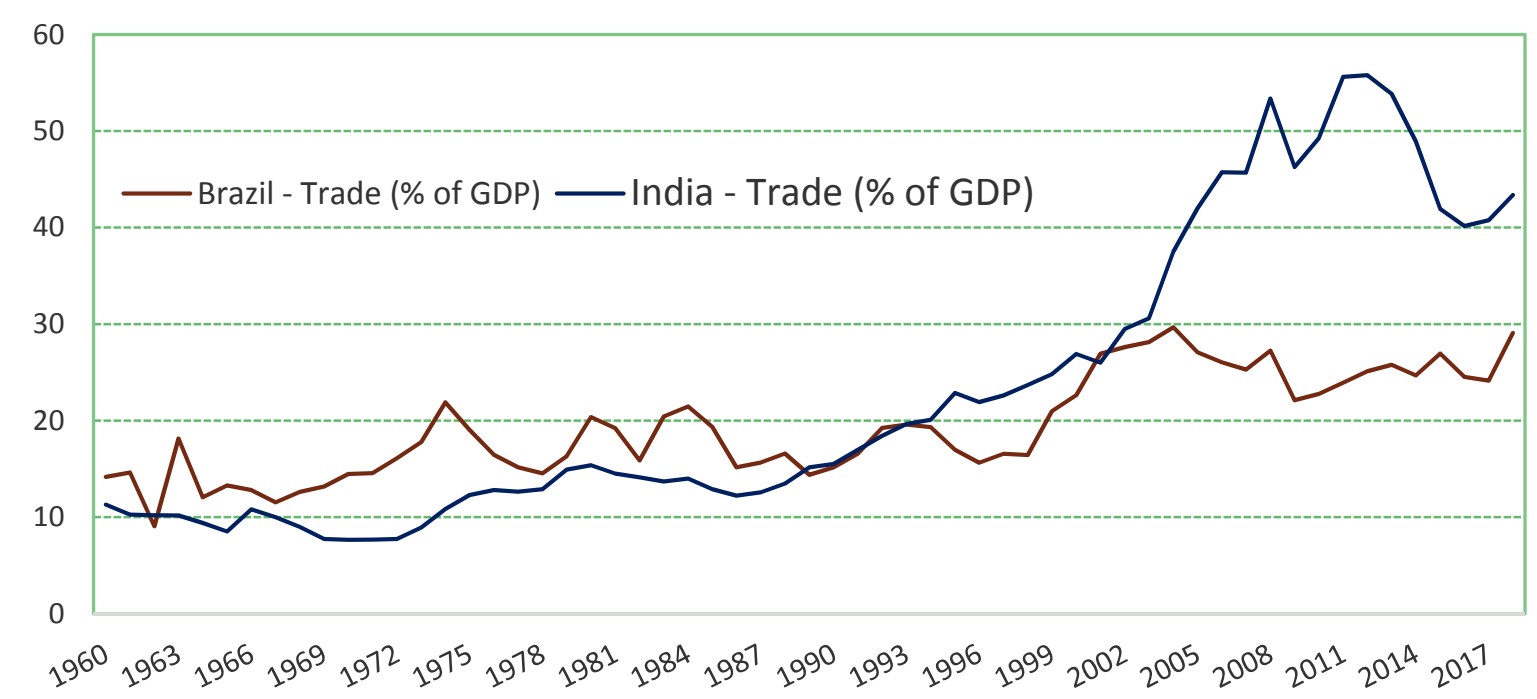

Figure 13. Comparison of international trade in relation to the GDP - Brazil and India

Source: Own preparation based on World Bank data, 2020.

\section{Factorial Analysis (Main Components)}

The Factorial Analysis model provides the description of the variability of correlated variables observed in a smaller number of unobserved variables that are linearly related to the original variables, known as latent variables. The observed variables are modeled as a linear combination of the common factors added to a random error,

$$
\begin{gathered}
Z_{1}=l_{11} F_{1}+l_{12} F_{2}+\cdots+l_{1 n} F_{n}+\varepsilon_{1} \\
Z_{2}=l_{21} F_{1}+l_{22} F_{2}+\cdots+l_{2 n} F_{n}+\varepsilon_{2} \\
\vdots \\
Z_{p}=l_{p 1} F_{1}+l_{p 2} F_{2}+\cdots+l_{p n} F_{n}+\varepsilon_{p}
\end{gathered}
$$

Being,

$\boldsymbol{Z}_{\boldsymbol{i}}=\frac{\boldsymbol{X}_{\boldsymbol{i}}-\boldsymbol{\mu}_{\boldsymbol{i}}}{\boldsymbol{\sigma}_{\boldsymbol{i}}}:$ standard variable

$\boldsymbol{X}_{\boldsymbol{i}}$ : original variable with average $\boldsymbol{\mu}_{\boldsymbol{i}}$ and variance $\boldsymbol{\sigma}_{\boldsymbol{i}}^{2}$

$\boldsymbol{\varepsilon}_{\boldsymbol{i}}$ : i-th random error, being $\boldsymbol{i}=\mathbf{1}, \ldots, \boldsymbol{p}$

$\boldsymbol{F}_{\boldsymbol{j}}$ : $\mathrm{j}$-th common factor, where $\boldsymbol{j}=\mathbf{1}, \ldots, \boldsymbol{n}$

$\boldsymbol{l}_{\boldsymbol{i} \boldsymbol{j}}$ : coefficient of the i-th standardized variable $\boldsymbol{Z}_{\boldsymbol{i}}$ in j-th factor $\boldsymbol{F}_{\boldsymbol{j}}$

Factorial Analysis assumes that a statistical model exists and uses regression model techniques to test hypotheses and is related to the analysis of major components.

Principal Component Analysis (Análise de Componentes Principais- $A C P$ ) is a multivariate covariance structure modeling technique that allows the transformation of original variables, initially correlated to each other, into a smaller set. Initially the technique was described by Pearson (1901) and some years later Hotelling $(1933,1936)$ made the description of practical computational methods, aiming to analyze the correlation structures (Hongyu, 2015). The main objective of Principal Component Analysis (PCA) is to explain the covariance and variance structure of a random vector, composed of $\boldsymbol{n}$ random variables, through the linear combination of the original variables, called principal components (Sandanielo, Hongyu et al., 2008).

The multivariate analysis is used to solve some problems, according to Regazzi (2000), they can be used to solve issues such as reducing the dimensionality of variables, grouping observations by similarities, among others. In this work the use of factor analysis and PCA will make possible to analyze the monthly performance index of the variables of a data set on the Brazil-India Trade Chain. 
In this work the use of factorial and PCA analysis makes it possible to analyze the monthly performance index of the variables of a data set on the Brazil-India Trade Chain. Eleven variables were initially analyzed, being $\boldsymbol{X}_{\mathbf{1}}$ : Trade Chain, $\boldsymbol{X}_{\mathbf{2}}$ : Brazil Exchange Rate, $\boldsymbol{X}_{\mathbf{3}}$ : Selic, $\boldsymbol{X}_{\mathbf{4}}$ : Installed Capacity, $\boldsymbol{X}_{\mathbf{5}}$ : FBCF Brazil, $\boldsymbol{X}_{\mathbf{6}}$ : Wage in Brazil, $\boldsymbol{X}_{\mathbf{7}}$ : Production - Brazil, $\boldsymbol{X}_{\mathbf{8}}$ : India's GDP and $\boldsymbol{X}_{\mathbf{9}}$ : Indian Interest Rate, $\boldsymbol{X}_{\mathbf{1 0}}$ : Indian Exchange Rate, $\boldsymbol{X}_{11}$ : Proportion of export and import India. Through the diagonalization of semi-defined positive symmetrical matrices the main components were obtained. The factors of this analysis represent the minimum number of causes that condition a maximum of existing variability, and with factor loads we estimate the communalities and specific variances.

In addition, the non-linear Granger causality test was applied in the article in question. The test evaluates whether the first time series (the Brazil Exchange Rate or the Selic Rate or the Brazilian Industrial Capacity or the Brazilian GFCF or the Brazilian Wage or the GDP of India or the Indian Interest Rate or the Indian Export and Import Ratio) causes the second (Trade Chain). The test uses two artificial neural networks MLP, one using only the target time series (Trade Chain) and the second using both time series (Trade Chain and one of the propset series as explanatory). Details about the test are found in the articles: Neural Granger Causality for Nonlinear Time Series published by: Alex Tank et al. (2018) and Economy Statistical Recurrent Units for Inferring Nonlinear Granger Causality published by: Khanna and Tan (2020). The NlinTS package of the R-Project was used to apply the test. The result of the test will be presented in section 7 .

\section{Machine Learning}

Machine Learning, for Géron (2017), is the science (and art) of computer programming so that they can learn from data. Machine learning can come in many forms. For Nilsson (1998) it refers to changes in systems performing tasks associated with artificial intelligence (AI). Such assignments involve, for example, reconnaissance, diagnosis, planning, robot control and prediction. In this article the use of machine learning is intended to make multivariate predictions of the chain between Brazil and India, using a set of economic variables. More specifically, we will use self-regressive time series prediction with cross-validation (CV).

Cross-validation techniques (CV) are widely used methods to evaluate the generalization of algorithms in regression classification and currently in time series forecasting (Sampaio, 2019).

Consider the purely self-regressive model of $\mathrm{p}$. order:

$$
y_{t}=g\left(x_{t}, \theta\right)+\epsilon_{t}
$$

In which $\boldsymbol{\varepsilon}_{\boldsymbol{t}}$ represents the shock or disturbance, $\boldsymbol{\theta}$ is a parameter vector, $\boldsymbol{x}_{\boldsymbol{t}} \in \mathbb{R}^{\boldsymbol{p}}$ consists of lagged values of $\boldsymbol{y}_{\boldsymbol{t}}$ and $\boldsymbol{g}\left(\boldsymbol{x}_{\boldsymbol{t}}, \boldsymbol{\theta}\right)=\boldsymbol{E}_{\boldsymbol{\theta}}\left[\boldsymbol{y}_{\boldsymbol{t}} \mid \boldsymbol{x}_{\boldsymbol{t}}\right]$. Additionally $\boldsymbol{g}(\cdot)$ can be a linear or non-linear function, or even a non-parametric function. Thus, $\boldsymbol{g}(\cdot)$ can be a completely unspecified function from the lagged values of $\boldsymbol{y}_{\boldsymbol{t}}$ to the p-umpteenth order (Bergmeir et al., 2017).

The time series incorporated with order $\mathrm{p}$ and a fixed forecast horizon of $\boldsymbol{h}=\mathbf{1}$ is matrically defined:

$$
\left[\begin{array}{ccccc}
y_{1} & y_{2} & \ldots & y_{p} & y_{p+1} \\
\vdots & \vdots & \vdots & \vdots & \vdots \\
y_{t-p} & y_{t-p+1} & \ldots & y_{t-1} & y_{t} \\
\vdots & \vdots & \vdots & \vdots & \vdots \\
y_{n-p} & y_{n-p+1} & \cdots & y_{n-1} & y_{n}
\end{array}\right]
$$

Thus, each row has the shape $\left[\boldsymbol{x}_{\boldsymbol{t}}^{\prime}, \boldsymbol{y}_{\boldsymbol{t}}\right]$ of the matrix (2) and the first $\boldsymbol{p}$ columns of the matrix contain predictors for the last column of the matrix.

In this method the sample is split in two, one is used for training and the other to validate the method used. It is worth noting that, according to Bergmeir et al. (2017), the k-CV method doubles in $\mathrm{K}$, where the training data is split into separate K sets, where $\boldsymbol{J}=\left\{\boldsymbol{J}_{\boldsymbol{1}}, \ldots, \boldsymbol{J}_{\boldsymbol{k}}\right\}$. Define $\boldsymbol{J}_{\boldsymbol{k}^{-}}=\cup_{\boldsymbol{j} \neq \boldsymbol{j}} \boldsymbol{J}_{\boldsymbol{j}}$, so that for a specific assessment k in cross validation, $\boldsymbol{J}_{\boldsymbol{k}}$ is used as the test set, and the remaining sets combined $\left(\boldsymbol{J}_{\boldsymbol{k}^{-}}\right)$, are used for model adjustment. Instead of reducing the training set by removing the $\boldsymbol{h}$ observations that precede and follow the $\boldsymbol{y}_{\boldsymbol{t}}$ observation from the test set, leaving out the entire set of lines corresponding to $\boldsymbol{t} \in \boldsymbol{J}_{\boldsymbol{k}}$ in the matrix. More details are in Bergmeir et al. (2017).

The objective function related to estimation is given by:

$$
\boldsymbol{Q}(\boldsymbol{\theta})=\sum_{\mathrm{t}=\mathbf{p}+\mathbf{1}}^{\mathrm{n}}\left(\mathbf{y}_{\mathrm{t}}-\mathbf{g}\left(\mathbf{x}_{\mathrm{t}}, \boldsymbol{\theta}\right)\right)^{2}
$$

By definition, $\widehat{\boldsymbol{\theta}}=\boldsymbol{a r g m i n}_{\boldsymbol{\theta} \in \boldsymbol{\theta}} \boldsymbol{Q}(\boldsymbol{\theta})$. Suppose $\left\{\widetilde{\boldsymbol{y}}_{t}\right\}_{t=1}^{m}$ is another process that has the same distribution as the sample data $\left\{\widetilde{y}_{t}\right\}_{t=1}^{n}$ and $\widetilde{x}_{t}=\left(\widetilde{y}_{t-1}, \widetilde{y}_{t-2}, \ldots, \widetilde{y}_{t-p}\right)$. 
The forecast error of the nonlinear models applied in this article is given as:

$$
P E=E\{\widetilde{y}-g(\widetilde{x}, \widehat{\theta})\}^{2}
$$

Where $\widehat{\boldsymbol{\theta}}$ is the solution for the system of non-linear equations

$$
\boldsymbol{q}(\widehat{\boldsymbol{\theta}})=\sum_{t=p+1}^{n}\left(\frac{\partial}{\partial \theta} g\left(\widetilde{x}_{t}, \widehat{\theta}\right)\right)(\widetilde{y}-g(\widetilde{x}, \widehat{\theta}))=\sum_{t=p+1}^{n}\left(\frac{\partial}{\partial \theta} g\left(\widetilde{x}_{t}, \widehat{\theta}\right)\right) \widetilde{\varepsilon}_{t}(\widehat{\theta})=\mathbf{0}
$$

Where $\tilde{\boldsymbol{\varepsilon}}_{\boldsymbol{t}}(\widehat{\boldsymbol{\theta}})=\widetilde{\boldsymbol{y}}-\boldsymbol{g}(\widetilde{\boldsymbol{x}}, \widehat{\boldsymbol{\theta}})$. By construction, $\tilde{\boldsymbol{\varepsilon}}_{\boldsymbol{t}}$ has the same distribution as $\boldsymbol{\varepsilon}_{\boldsymbol{t}}$. At the same time, we consider the PE estimate by cross-validation. Here the training sample is $\left\{\left(\boldsymbol{x}_{\boldsymbol{j}}, \boldsymbol{y}_{\boldsymbol{j}}\right) ; \boldsymbol{j}=\boldsymbol{p}+\mathbf{1}, \ldots, \boldsymbol{n}, \boldsymbol{j} \neq \boldsymbol{t}\right\}$ the test sample is $\left\{\left(\boldsymbol{x}_{\boldsymbol{t}}, \boldsymbol{y}_{\boldsymbol{t}}\right)\right\}$. We leave out the entire line of matrix 2 corresponding to the test system. A PE estimator using cross validation is $\widehat{\boldsymbol{P E}}=\frac{1}{n-\boldsymbol{p}} \sum_{t=\boldsymbol{p}+\mathbf{1}}^{n}\left\{\boldsymbol{y}_{\boldsymbol{t}}-\boldsymbol{g}\left(\boldsymbol{x}_{\boldsymbol{t}}, \widehat{\boldsymbol{\theta}}_{-t}\right)\right\}^{2}$ where $\widehat{\boldsymbol{\theta}}_{-\boldsymbol{t}}$ is the leave-one-out estimator of $\boldsymbol{\theta}$, which is the solution for the following system of non-linear equations:

$$
q\left(\widehat{\theta}_{-t}\right)=\sum_{\substack{j=p+1 \\ j \neq t}}^{n}\left(\frac{\partial}{\partial \theta} g\left(x_{j}, \widehat{\theta}_{-t}\right)\right)\left(y_{j}-g\left(x_{j}, \widehat{\theta}_{-t}\right)\right)=\sum_{\substack{j=p+1 \\ j \neq t}}^{n}\left(\frac{\partial}{\partial \theta} g\left(x_{j}, \widehat{\theta}_{-t}\right)\right) \varepsilon_{j}\left(\widehat{\theta}_{-t}\right) 0
$$

Where $\boldsymbol{q}\left(\widehat{\boldsymbol{\theta}}_{-t}\right)$ is obtained by distinguishing:

from $\boldsymbol{\theta}$.

$$
Q_{-t}(\theta)=\left(\sum_{\substack{j=p+1 \\ j \neq t}}^{n}\left(y_{j}-g\left(x_{j}, \theta\right)\right)^{2}\right)
$$

In this article we used three models for trade chain forecasting (cross-validated LASSO, neural networks and non-tuned Random Forest) and compared the result. We will describe below the method that presented the best performance.

LASSO (Least absolute shrinkage and selection operator) is a multivariate regression technique, based on a penalty on the quadratic error function. This is formalized as an optimization problem. According to Mourthé (2017), LASTE is a technique used to control the overfitting phenomenon. The technique in question involves adding a term that penalizes large coefficients and, consequently, decreases the complexity of the model.

In LASSO, according to Ramasubramanian and Singh (2019), a penalty term against complexity is added to reduce the degree of excessive adjustment or the variation of the model by adding bias. Therefore, the objective function of minimizing can be written as follows:

\section{Regularization cost $=$ Cost + regularization penalty.}

In LASSO regularization, the general form is given by the objective function:

$$
\frac{1}{N} \sum_{i=1}^{N} f\left(x_{i}, y_{i}, \alpha, \beta\right)
$$

The version of the LASSO regularization for the estimator will be the solution for:

$$
\min _{\alpha, \beta} \frac{1}{N} \sum_{i=1}^{N} f\left(x_{i}, y_{i}, \alpha, \beta\right) \text { subject to }\|\beta\|_{1} \leq t .
$$

Where $\boldsymbol{\beta}$ is penalized, while $\alpha$ is free to have any value allowed.

The objective function for penalized logistic regression uses the negative binomial "log-likelihood", and is as follows:

$$
\min _{\left(\beta_{0}, \beta\right)<}-\left[\frac{1}{N} \sum_{i=1}^{N} y_{i}\left(\beta_{0}+x_{i}^{\gamma} \beta\right)-\log \left(1+e^{\left(\beta_{0}+x_{i}^{\gamma} \beta\right)}\right)\right]+\lambda\left[(1-\alpha)\|\beta\|_{2}^{2} / 2+\alpha\|\beta\|_{1}\right]
$$

For more details on the methodology applied in this article, research in Bergmeir et al. (2017), Mourthé (2017) and in Ramasubramanian and Singh (2019).

\section{Results}

For the analyses, data were collected by monthly variation in relation to the same month of the previous year; Table 2 presents the variables used for modeling. 
Table 2. Variables per collection site

\begin{tabular}{ll}
\hline Variables & Data collection site \\
\hline Trade Chain & Ministério da Indústria, Comércio Exterior e Serviços (MDIC) \\
Brazil Exchange Rate & Banco Central do Brasil (BACEN) \\
SELIC & Banco Central do Brasil (BACEN) \\
Installed Capacity - BR & Porta da indústria (CNI) \\
Gross Fixed Capital Formation (GFCF) - Brazil & Banco Central do Brasil (BACEN) \\
Real minimum wage (last month) - Brazil & Instituto de Pesquisa Econômica Aplicada (IPEA) \\
Industrial Production - Brazil & Banco Central do Brasil (BACEN) \\
GDP - India & Federal Reserve Bank St.Louis \\
Interest rate - India & Federal Reserve Bank St.Louis \\
India Exchange Rate & Federal Reserve Bank St.Louis \\
Propo of Exp and Imp - India & Federal Reserve Bank St.Louis \\
\hline
\end{tabular}

Source: Own preparation based on analyzed data.

The descriptive statistics presented in Table 3, where the minimum, avarage, maximum and the variance within each variable are described, for the monthly period from January 1997 to November 2019 were obtained. The values are shown as monthly variation rate, that is, the Chain Trade variable presented in the analyzed period a variance of 0.0479 and an average rate of 0.04395 , the variable with less variability and average was the Installed Capacity in Brazil with 0.0005 and -0.0002 respectively.

Table 3. Descriptive statistics of the variables

\begin{tabular}{lllll}
\hline Variables & Minimum & Avarage & Maximum & Variance \\
\hline Trade Chain & $-0,3408$ & 0,04395 & 2,84 & 0,0479 \\
Exchange Rate - Brazil & $-0,2919$ & $-0,0563$ & 0,5916 & 0,0345 \\
SELIC & $-0,8314$ & $-0,0563$ & 0,6665 & 0,0751 \\
Installed Capacity - BR & $-0,0688$ & $-0,0002$ & 0,0687 & 0,0005 \\
GFCF - Brazil & $-0,2373$ & 0,0162 & 0,2680 & 0,0085 \\
Wage - Brazil & $-7,84$ & 0,0116 & 1,05 & 0,2313 \\
Industrial Production - Brazil & $-0,1686$ & 0,0091 & 0,1688 & 0,0033 \\
GCP- India & $-0,0577$ & 0,0513 & 0,1859 & 0,0019 \\
Interests - India & $-0,25$ & $-0,0217$ & 0,58 & 0,0179 \\
Exchange rate - India & $-0,1228$ & 0,0062 & 0,1527 & 0,0032 \\
Propo of Exp and Imp - India & $-0,3030$ & $-0,0115$ & 0,3288 & 0,0152 \\
\hline
\end{tabular}

Source: Own development based on collected data (Table 2).

Figure 14 presents the Trade Chain series, where the blue line represents the average rate. Note that the values presented are in accordance with Table 3 , where the average is approximately 0.043 , minimum -0.34 and reaches its maximum point of 2.84 in 2011. 


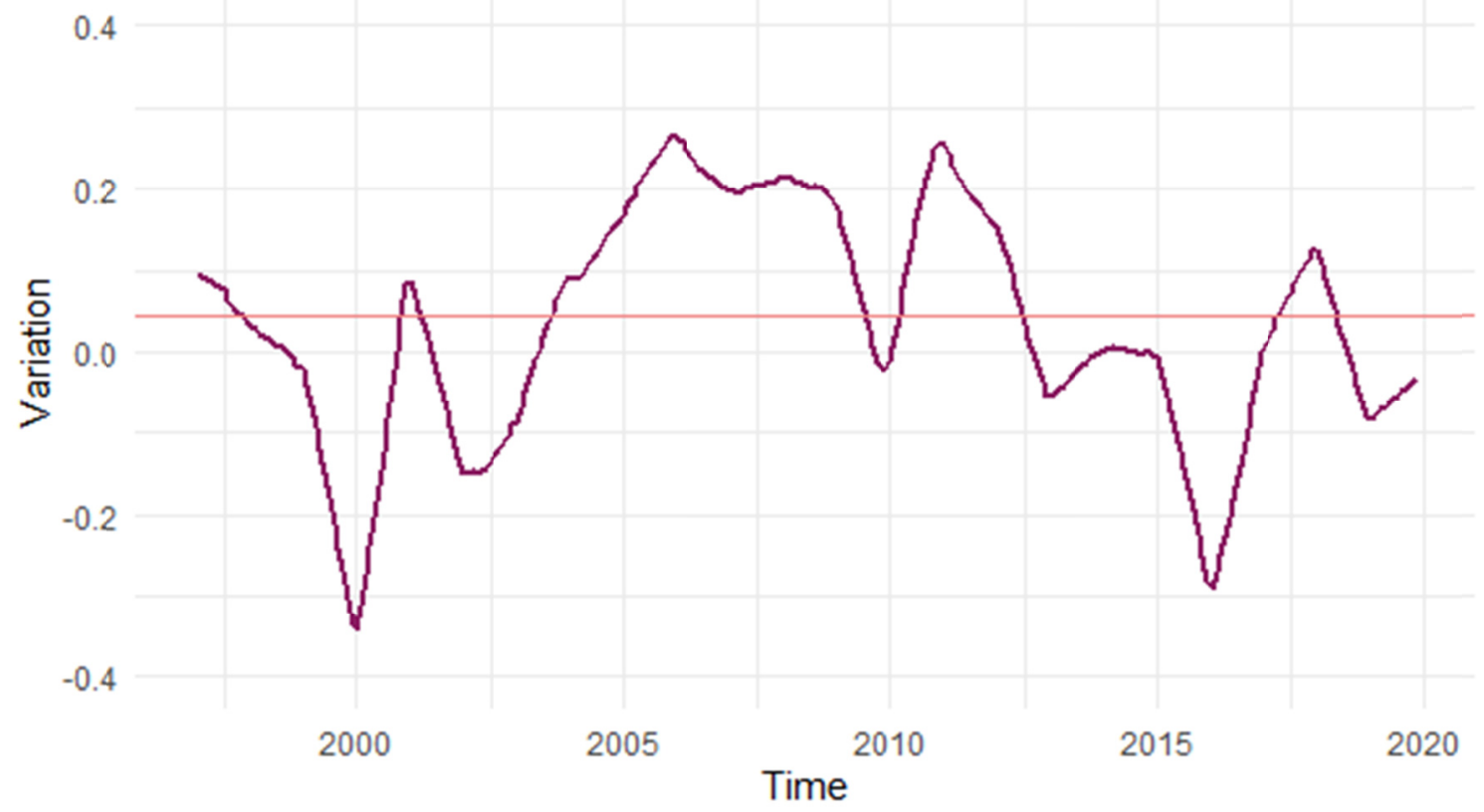

Figure 14. Trade chain

Source: Own preparation, based on data collected at MDIC, 2019.

Figure 15 presents the variables related to the Brazilian data, as well as in Table 3 it is observed the maximum and minimum points of the series. It is noticed that the Selic rate series presents a behavior of larger variability in the analyzed period.
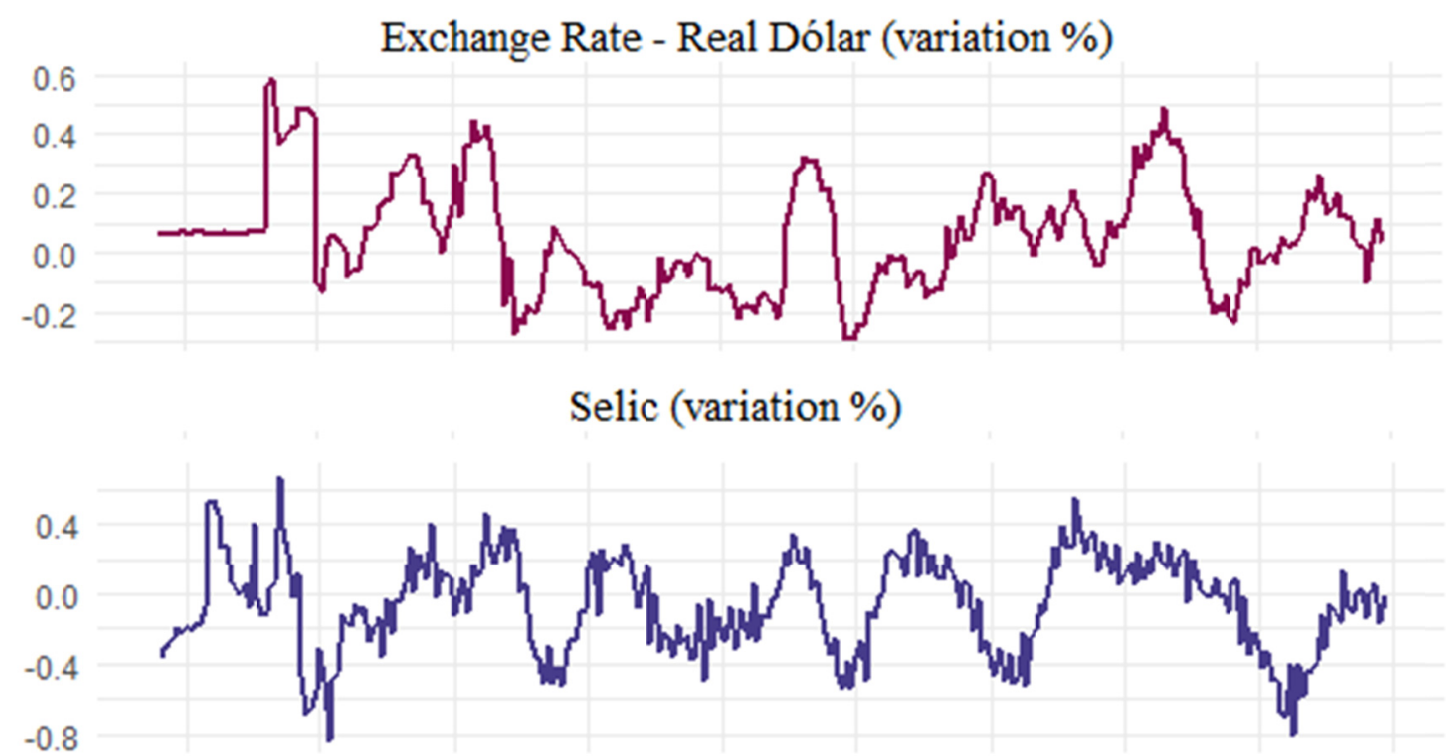


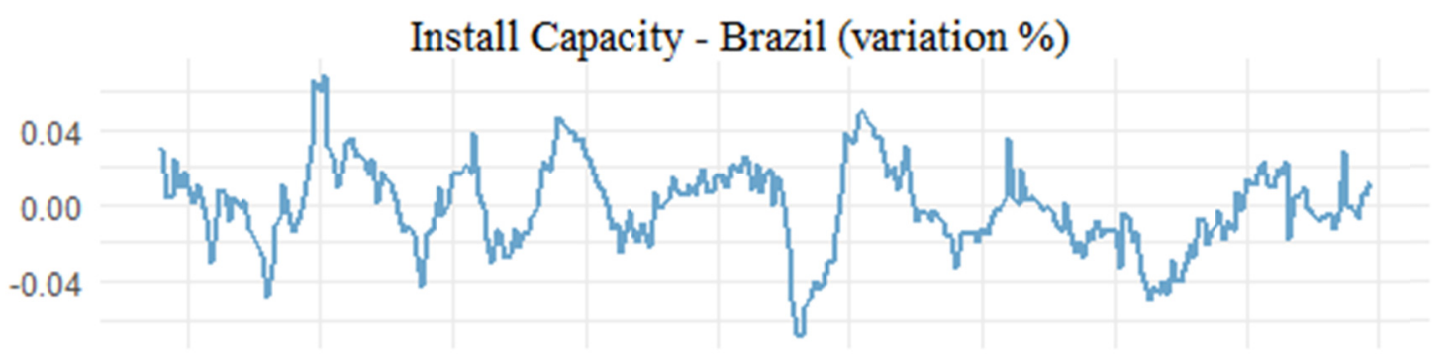

Gross Fixed Capital Formation(GFCF) - Brazil (variation \%)

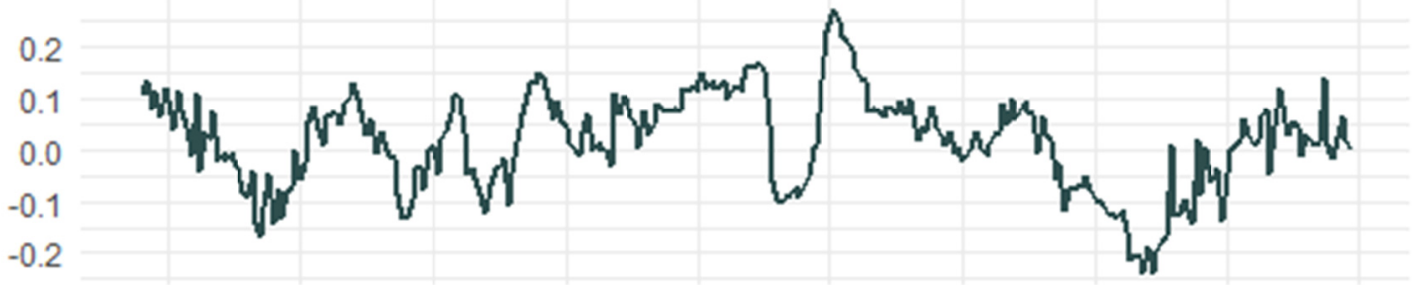

\section{Industrial Production - Brazil (variation \%)}

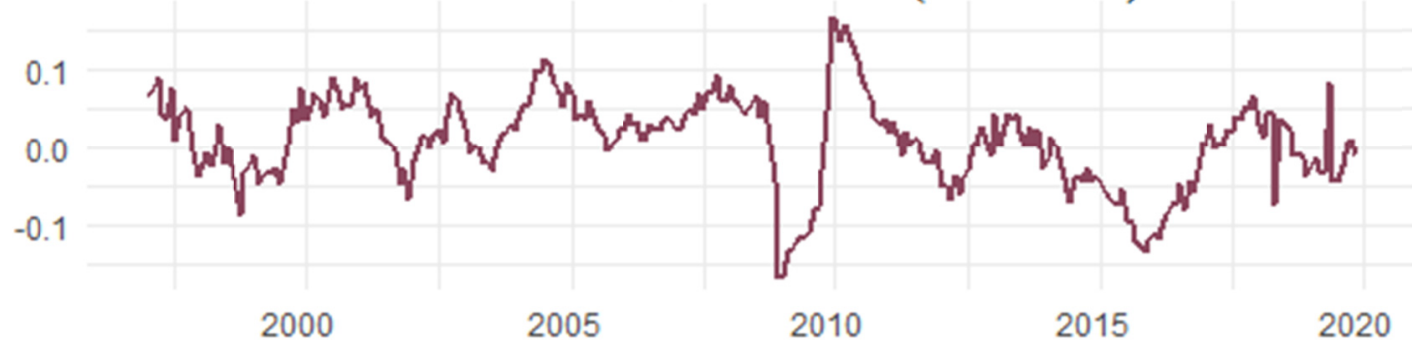

Figure 15. Variables - Brazil

Source: Own preparation based on collected data (Table 2).

In Figure 16 the variables related to India data are observed, as well as in Table 3 the graphics present the maximum and minimum points of the series. It is noticed that the interest rate series presents a stable behavior around 0 in the period from 2004 to 2012. 


\section{Exchange rate India}

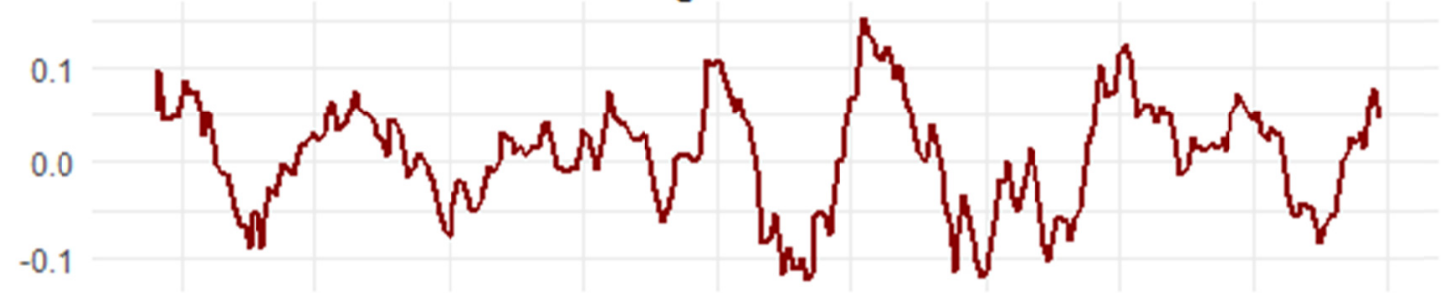

Interest rate India

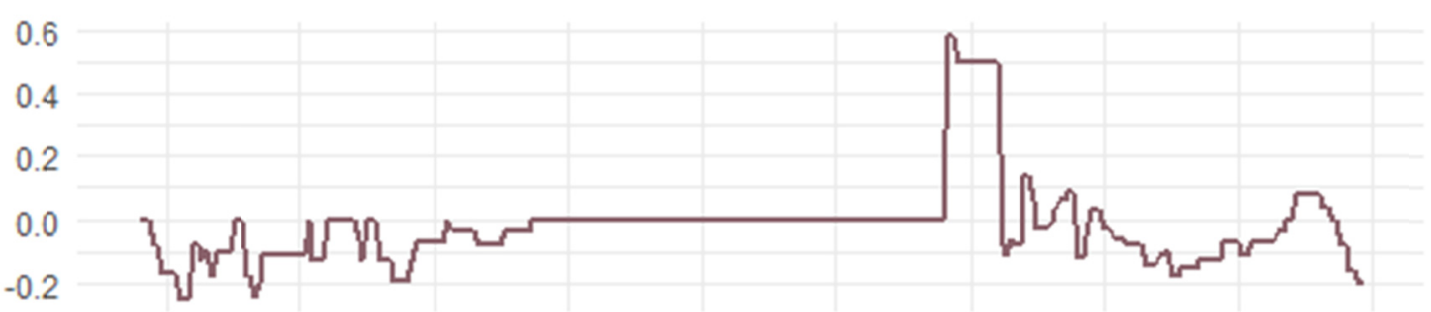

Prop of Exp and Imp - India (variation\%)

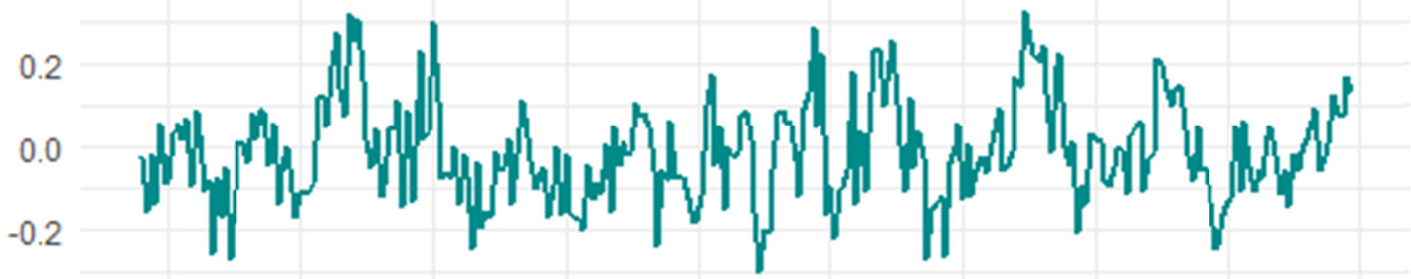

\section{GDP India}

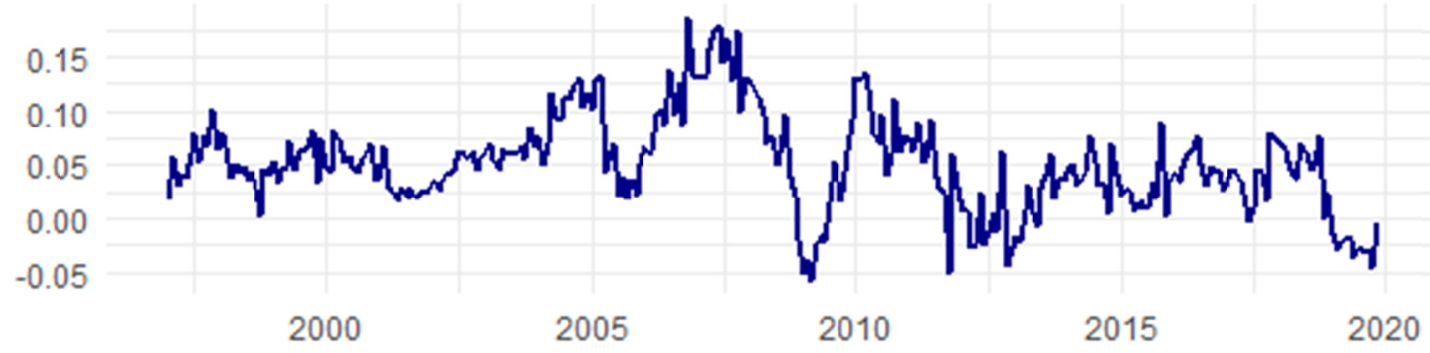

Figure 16. Variables - India

Source: Own preparation based on collected data (Table 2).

To analyze the monthly performance rate of the variables of the data set we applied factor analysis and PCA techniques. As mentioned above, eleven variables were initially analyzed, being $\boldsymbol{X}_{\mathbf{1}}$ : Trade Chain, $\boldsymbol{X}_{\mathbf{2}}$ : Brazil Exchange Rate, $\boldsymbol{X}_{3}$ : Selic, $\boldsymbol{X}_{\mathbf{4}}$ : Installed Capacity, $\boldsymbol{X}_{\mathbf{5}}$ : GFCF Brazil, $\boldsymbol{X}_{\mathbf{6}}$ : Wage in Brazil, $\boldsymbol{X}_{7}$ : Production - Brazil, $\boldsymbol{X}_{\mathbf{8}}$ : GDP India and $\boldsymbol{X}_{\mathbf{9}}$ : Interest Rate India, $\boldsymbol{X}_{\mathbf{1 0}}$ : Exchange Rate India, $\boldsymbol{X}_{\mathbf{1 1}}$ : Proportion of export and import India. To verify if the use of factor analysis technique is appropriate, the Bartlett and Kaiser-Meyer-Olkin (KMO) sphericity test was applied.

Bartlett's sphericity test checks whether all correlations within the matrix of correlations are significant, the hypothesis to be tested are:

\section{$\left\{H_{0}:\right.$ Group variances are the same. $H_{1:}$ Group variances are different.}

After applying the test we obtained p-value $<2.2 \mathrm{e}-16$, that is, at a $5 \%$ significance level we have evidence to reject the null hypothesis $\boldsymbol{H}_{\mathbf{0}}$, so we conclude that the variances of the groups compared are different, so 
according to Bartlett's test the use of factor analysis is appropriate.

The KMO (Kaiser-Meyer-Olkin) test was used to evaluate the adequacy of the sample size. The result of this test varies between 0 and 1 , where 0 indicates inadequate for factor analysis and acceptable if greater than 0.5. After the application of the test, $\mathrm{KMO}=0.79$ was obtained, that is, the sample is inadequate for factor analysis.

Once the tests were performed, factor analysis was applied and the main components were obtained through diagonalization of semi-defined positive symmetrical matrices. The first principal component accounts for about $33 \%$ of the total variance of standardized data, while if we take the first seven components the proportion is about $90 \%$ of the total variance. These factors represent the minimum number of causes that condition a maximum of existing variability. Therefore, the factorial analysis is based on 7 factors, and with the factorial loads we estimate the specific variances and the communalities that are indexes attributed to the original variable that express in percentage how much of the variability of each variable is explained by the model. It is designated by communality the proportion of the variance of each variable explained by the common factors. The communalities vary between 0 and 1 , when their value in each variable is less than 0.6 one should think about increasing the sample or eliminating variables. Observing the results of the communalities and specific variances (Table 4) it was opted for the withdrawal of no variable, since all presented communality greater than 0.6 .

Table 4. Main component analysis' result

\begin{tabular}{llll}
\hline Variables & Communalitie & Single Variance & Variance \\
\cline { 2 - 4 } Trade Chain & 0.8279501 & 0.1720498873 & 1 \\
Brazil Exchange Rate & 0.7856589 & 0.2143410921 & 1 \\
Selic & 0.9703536 & 0.0296463506 & 1 \\
Installed Capacity - BR & 0.8831194 & 0.1168806479 & 1 \\
GFCF - Brazil & 0.8576053 & 0.1423946834 & 1 \\
Wage - Brazil & 0.9995370 & 0.0004629976 & 1 \\
Production - Brazil & 0.9235021 & 0.0764979235 & 1 \\
GDP - India & 0.7680268 & 0.2319731549 & 1 \\
Interest - India & 0.8249692 & 0.1750307841 & 1 \\
India Exchange Rate & 0.8509479 & 0.1490521019 & 1 \\
Prop de Exp and Imp - India & 0.9831981 & 0.0168019304 & 1 \\
\hline
\end{tabular}

Source: Own preparation based on analyzed data (Table 2).

Table 5 presents the results of the non-linear causality test for each variable; the test aims to overcome the limitations of the use of simple correlations between variables. This distinction is important, because correlations do not imply by themselves in causality, that is, not necessarily correlated variables will always present a cause and effect relationship.

The identification of a statistical relationship between two variables, as strong as it is, is not enough to establish a causal relationship between them, so we used the non-linear Granger causality test to determine the causal direction between the variables, stipulating that $\boldsymbol{X}$ causes $\boldsymbol{Y}$, if values of $\boldsymbol{X}$ help to predict the present value of $\boldsymbol{Y}$, then we have $\boldsymbol{Y}$ :Trade Chain and $X$ : Other variables, the hypotheses tested were,

$$
\left\{\begin{array}{l}
H_{0}: X \text { does not cause } Y . \\
H_{1}: X \text { causes } Y .
\end{array}\right.
$$

We can observe in Table 5 the results of the $\boldsymbol{p}$-value, so at the level of significance of $5 \%$ we have evidence to reject the null hypothesis $\boldsymbol{H}_{\mathbf{0}}$, so we conclude that all the variables $\boldsymbol{Y}$ cause $\boldsymbol{X}$. 
Table 5. Result of causality test - non-linear

\begin{tabular}{ll}
\cline { 2 - 3 } Non-linear causality test & p-value \\
\cline { 2 - 3 } Brazil Exchange Rate & 0.000 \\
Selic & 0.000 \\
Installed Capacity - BR & $2.65 \mathrm{e}-14$ \\
GFCF - Brazil & $1.32 \mathrm{e}-14$ \\
Wage - Brazil & 0.000 \\
Production - Brazil & $9.59 \mathrm{e}-17$ \\
GDP - India & 0.00283 \\
Interest - India & $4.11 \mathrm{e}-02$ \\
India Exchange Rate & 0.000 \\
Propo de Exp and Imp - India & $3.47 \mathrm{e}-12$ \\
\hline
\end{tabular}

Source: Own preparation based on analyzed data (Table 2).

After the statistical study about the dependence between the variables, to perform the Chain Trade forecast between Brazil and India we applied the Machine Learning technique, in a more specific way, we used the cross-validated LASSO. In this article, we initially used three models for trade chain forecasting (cross-validated LASSO, Neural Networks and non-tuned Random Forest) and compared the metrics performances.

The error measures used in this work were MAE, which is the average absolute error represented by the expression:

$$
M A E=\frac{1}{T} \sum_{t=1}^{T}\left|Y_{t}^{S}-Y_{t}^{a}\right|
$$

The MAPE, which consists of the mean percentage absolute error:

$$
M A P E=100 \frac{1}{T} \sum_{t=1}^{T}\left|\frac{\left(Y_{t}^{s}-Y_{t}^{a}\right)}{Y_{t}^{a}}\right|
$$

The SMAPE, symmetric mean absolute percentage error:

$$
S M A P E=\operatorname{mean}\left(\frac{200 *\left|Y_{t}^{S}-Y_{t}^{a}\right|}{\left|\left(Y_{t}^{S}+Y_{t}^{a}\right)\right|}\right)
$$

MDAPE, which calculates the median percentage absolute error between the forecast and the results,

$$
p_{t}=\left|\frac{\left(Y_{t}^{s}-Y_{t}^{a}\right)}{Y_{t}^{a}}\right|
$$

We have then that $\boldsymbol{Y}_{\boldsymbol{t}}^{s}$ is the predicted value of $\boldsymbol{Y}_{\boldsymbol{t}}, \boldsymbol{Y}_{t}^{\boldsymbol{a}}$ is the effective value, that is, the observed value and $\boldsymbol{T}$ represents the number of periods in the simulation (Armstron, 1978).

The result of the error measurements, both in the training part and the validation part, are described in Table 6 .

Table 6. Model result

\begin{tabular}{lllllllll}
\hline \multirow{2}{*}{ Models } & \multicolumn{3}{l}{ Error Measures (training) } & \multicolumn{5}{c}{ Error Measures (validation) } \\
\cline { 2 - 9 } & MAE & MAPE & SMAPE & MDAPE & MAE & MAPE & SMAPE & MDAPE \\
\hline LASSO & 0.8 & 133.7 & 173.3 & 0.79 & 0.92 & 102.53 & 165.57 & 101.52 \\
RF (Random Forest) & 0.8 & 173.3 & 170.4 & 0.8 & 0.91 & 105.87 & 177.73 & 105.28 \\
RN (Neural Networks) & 0.62 & 128.62 & 189.1 & 0.9 & 1.16 & 141.77 & 174.4 & 174.4 \\
\hline
\end{tabular}

Source: Own preparation based on analyzed data (Table 2).

For the validation of the models we reserve the last 24 observations of the series that contains the Trade Chain. Regarding the errors in the training part, the LASSO model presented the smallest MDAPE (Median Absolute Percentage Error), while the RN (Neural Networks) metric presented the smallest MAE (Mean Absolute Error) and MAPE (Mean Absolute Percentage Error). Regarding the errors in the validation part, LASSO showed the technique with the smallest measures (MAPE, SMAPE and MDAPE). Considering the error measures, it was decided to adopt LASSO as the most adequate model for predicting the Trade Chain between Brazil and India.

It is worth mentioning here that for the modeling the time series were standardized, because it considerably increases the accuracy of the models applied. Another point to be emphasized is that the tests applied here show 
that the Trade Chain is related to the macroeconomic variables presented in Table 5. Corroborating the thesis that the narrowing of the trade relationship between India and Brazil generates positive impacts on the economy of both countries.

The three models chosen for Trade Chain Forecasting are robust metrics that allow for the analysis of linear and non-linear dependence between variables. Additionally, they allow the analysis and capture of long-term dependence, namely, the model that presented the best performance (cross-validated LASSO) uses all macroeconomic series presented in Table 5 with dependence of up to 60 lags. Since these variables' present dependence of up to 6 years it is important that the authorities look carefully at international relations and the economy. Because of the intensification in trade between the two countries (Brazil and India) and the potential growth of India, both in population and GDP, the increasingly intense trade alliance can be highly beneficial for Brazil.

\section{Conclusion}

This study was carried out with the objective of analyzing the trade relationship between Brazil and India, based on the Trade Chain and the macroeconomic variables of both countries, in order to generate a result that allows the visualization of this trade for the next years.

India is well known as a trading power, currently with the fifth highest GDP in the world, which has been in a crescendo for more than 20 years and is expected to remain so at least until 2030. Population factors, such as the second largest world population, with the capacity to become the first in 5 years and having $80 \%$ of its population under 45 years of age, are demonstrations that add to the justification of the country's promising trade. However, socio-cultural issues still create barriers to the development of the Indian market, such as the fact that $65.5 \%$ of the population still lives in rural areas, generating a high loss of production, which is characterized as a great challenge in the search for a more skilled workforce.

For Brazil, currently, trade with India becomes favorable as an option to trade with China, seeking more profitable business as regards imports, mainly of manufactured products, which represent about $90 \%$ of this type of business. In addition to export, which is practiced in mixed quantity between basic products, semi-finished and manufactured.

In this article we used factor and PCA analysis to examine the monthly performance index of the variables of a data set on the Brazil-India Trade Chain. Initially, eleven variables were analyzed: Trade Chain, Brazil Exchange Rate, Selic, Installed Capacity, GFCF Brazil, Wage in Brazil, Production - Brazil, India's GDP and India's Interest Rate, India's Exchange Rate, India's Export and Import Ratio. Through the diagonalization of semi-defined positive symmetrical matrices, the main components were obtained. The first principal component accounts for about $26 \%$ of the total variance of standardized data, while if we take the first seven components the proportion is about $94 \%$ of the total variance.

The test evaluates if the first time series (the GDP of Brazil or the Exchange Rate of Brazil or the Selic Rate or the Industrial Capacity of Brazil or the GDP of India or the Interest Rate of India or the Exchange Rate of India) causes the second (Trade Chain). The results (P-values) demonstrated the causality of the above-mentioned variables, corroborating with the result of factor analysis.

After the statistical study about the dependence between the variables, we applied the technique of Machine Learning, in a more specific way, to perform the current trade forecast between Brazil and India. The results were satisfactory, and thus, we selected a forecasting technique with satisfactory results regarding the multivariate trade chain projection between Brazil and India.

In conclusion, India has an increasing share of its trade balance in GDP, which means that the country has increasingly developed significant trade relations for its economic development, making it attractive for Brazil to strengthen trade relations. Therefore, for Brazil, this trade partnership, which has intensified significantly since 2005 , presents an opportunity for economic growth.

\section{References}

Apexbrasil. (2012). Agência Brasileira de promoção de exportações e investimentos. Perfil e Oportunidades Comerciais.

Araujo JR, J. T., \& Costa, K. P. d. (2010). Abertura comercial e inserção internacional: os casos do Brasil, China e Índia. In R. Baumann (Org.), O Brasil e os demais BRICs: comércio e política. Brasília: Cepal/Ipea.

Banco, M. (2020). Retrieved February 8, 2020, from https://data.worldbank.org/indicator/

Campos, F. A. (2018). O BRICs e sua influência na governança do sistema internacional, Universidade Federal 
da Bahia, 2018. Retrieved April 26, 2020, from https://repositorio.ufba.br/ri/bitstream/ri/28202/1/Disserta\%C3\%A7\%C3\%A30\%20de\%20Mestrado\%20-\% 20Felipe\%20Amorim\%20Campos-converted.pdf

Ducioni, D. D., Zili, J. C., Freire, P. D. S., Vieira, A. C. P. (2020). As relações comerciais brasileiras com países em diferentes niveis de desenvolvimento: Negociações e acordos internacionais. II congresso sul catarinense de administração e comércio exterior - Santa Catarina, 2018. Retrieved January 29, 2020, from periodicos.unesc.net $>$ admcomex $>$ article $>$ download

FMI (Fundo Monetário Internacional). (2019). World Outlook Database. Retrieved February 6, 2020, from https://www.imf.org/en/Publications/SPROLLS/world-economic-outlookdatabases\#sort=\%40imfdate $\% 20 \mathrm{~d}$ escending

Geron, A. (2017). Hands-On Machine Learning with Scikit-Learn and TensorFlow Concepts, Tools, and Techniques to Build Intelligent Systems ( $1^{\mathrm{a}}$ ed.). Califórnia: O’Reilly Media Inc.

Guimaraes, S. P. (1998). Desafios e dilemas dos grandes países periféricos: Brasil e Índia. Revista Brasileira Política Internacional, 4l(1). https://doi.org/10.1590/S0034-73291998000100006

Haffner, J. A. H., \& Monteiro, L. D. O. V. (2011). As relações econômicas entre Índia e Brasil: Trajetória e perspectivas. Universidade Federal do Rio grande do Sul - UFRGS, Porto Alegre - RS, 2011. Retrieved January 29, 2020, from www.proceedings.scielo.br > pdf > enabri

Hongyu, K. (2015). Comparação do GGE-biplot ponderado e AMMI-ponderado com outros modelos de interação genótipo $\times$ ambiente (p. 155). Tese (Doutorado em Estatística e Experimentação Agronômica) - Escola Superior de Agricultura "Luiz de Queiroz", Universidade de São Paulo, Piracicaba.

Hongyu, K., Sandanielo, Vera L. M., Junior, G. J. D. O. (2015). Análise de Componentes Principais: resumo teórico, aplicação e interpretação. $E \& S$ - Engineering and Science, 5(1). https://doi.org/10.18607/ES201653398

Hotelling, H. (1933). Analysis of a Complex of Statistical Variables into Principal Components. Journal of Educational Psychology, 24(6\&7), 417-441, 498-520. https://doi.org/10.1037/h0070888

IBGE. (2019). Sistema de Contas Nacionais Trimestrais - SCNT. Séries históricas: PIB a preços de mercado Taxa acumulada em 4 trimestres (\%), $1^{\circ}$ trimestre $1996-3^{\circ}$ trimestre 2019. Retrieved February 4, 2020, from https://www.ibge.gov.br/estatisticas/economicas/contas-nacionais/9300-contas-nacionais-trimestrais.html?= $\& \mathrm{t}=$ series-historicas\&utm_source=landing\&utm_medium=explica\&utm_campaign=pib\#evolucao-taxa

IPEA. (2018). Brics debatem os desafios e potencialidades para o futuro do bloco. Retrieved February 5, 2020, from http://www.ipea.gov.br/portal/index.php?option=com_content\&view=article\&id=34467

Junior, H. R. (2012). O Brasil e as negociações no sistema GATT/OMC: uma análise da Rodada Uruguai e da Rodada Doha. Universidade de São Paulo, Faculdade de Filosofia, Letras e Ciências Humanas, São Paulo $\begin{array}{lllll}\text { SP. } & \text { Retrieved } & \text { February } & 2020, & \text { from }\end{array}$ https://www.teses.usp.br/teses/disponiveis/8/8131/tde-14032013-121719/publico/2012_HaroldoRamanziniJ unior.pdf

KNOEMA. (2019). Population Estimates and Projections. Retrieved February 1, 2020, from https://pt.knoema.com/WBPEP2018Oct/population-estimates-and-projections

Lins, H. N. (2020). Interações entre o Brasil e a Índia no alvorecer do século 21. Revista de economia, Universidade Federal do Paraná. Retrieved April 26, 2020, from https://revistas.ufpr.br/economia/article/view/54103/38857

MIDC. (2020). Ministério da Economia indústria, comércio exterior e serviços. Comex Vis: Países Parceiros, Retrieved February 7, 2020, from http://comexstat.mdic.gov.br/pt/geral

Mourthe, A. C. L. (2017). Um estudo da aplicação do LASSO para seleção de instâncias. UNIRIO, Centro de Ciências Exatas e Tecnologia, Escola de Informática Aplicada. Retrieved March 22, 2020, from http://bsi.uniriotec.br/tcc/textos/201712AdrianoCabral.pdf

Niewierowski, M. V. (2016). O comércio exterior brasileiro e suas relações comerciais. Assembleia Legislativa Estado do Rio Grande do sul, Comissão do Mercosul e Assuntos Internacionais (Biênio 2015-2016). Retrieved January 28, 2020, from http://www.al.rs.gov.br > repdcp_m505 > CMPMAI > ComercioExterior

Nilsson, N. J. (1998). Introduction to machine learning. Nils J. Nilsson Robotics Laboratory Department of Computer Science Stanford University Stanford, CA 94305. Retrieved April 26, 2020, from 
https://ai.stanford.edu/ nilsson/MLBOOK.pdf

O’Neill, J. (2001). Building better global economic BRICs. Global Economic Paper 66, Goldman Sachs Economic Research Group, London, 30th Nov.

OECD. (2020). Real GDP forecast (indicator). Retrieved February 7, 2020, from https://data.oecd.org/gdp/real-gdp-forecast.htm\#indicator-chart

OECD. (2020). Real GDP long-term forecast (indicator). Retrieved February 7, 2020, from https://data.oecd.org/gdp/real-gdp-long-term-forecast.htm\#indicator-chart

Pearson, K. (2010). On Lines and Planes of Closest Fit to Systems of Points in Space. The London, Edinburgh, and Dublin Philosophical Magazine and Journal of Science (Series 6), 2(11), 559-572. https://doi.org/10.1080/14786440109462720

Pianna, A. (2007). O desenvolvimento econômico, tecnológico e industrial recente da índia: origens, causas e $\begin{array}{lllll}\text { perspectivas. } & \text { GEEIN. } & \text { Retrieved 26, } & \text { 2020, fril }\end{array}$ https://geein.fclar.unesp.br/admin/dbo/upload/files/180108Monografia_Anelise.pdf

Ramasubramanian, K., \& Singh, A. (2019). Machine Learning Using $R$ with Time Series and Industry-Based Use Cases in R. Califórnia. Apress. https://doi.org/10.1007/978-1-4842-4215-5

Regazzi, A. J. (2000). Análise multivariada, notas de aula INF 766. Departamento de Informática da Universidade Federal de Viçosa, v.2.

Sampaio, I. G., Bernardini, F., Paes, A., Andrade, E. D. O., \& Viterbo, J. (2019). Avaliação de Modelos de Predição e Previsão Construídos por Algoritmos de Aprendizado de Máquina em Problemas de Cidades Inteligentes. $\quad$ Retrieved

from https://sol.sbc.org.br/livros/index.php/sbc/catalog/download/33/133/319-1?inline=1

Tinoco, G., \& Giambiagi, F. (2018). O crescimento da economia brasileira 2018-2023. Departamento de Pesquisa Econômica do BNDES. Retrieved April 46, 2020, from https://web.bndes.gov.br/bib/jspui/bitstream/1408/14760/1/Perspectivas\%202018-2023_P.pdf

\section{Notes}

Note 1. Original Quote: Brasil e Índia compartilham semelhanças e interesses comuns por serem "grandes países periféricos", o que os distingue radicalmente dos países médios e pequenos da periferia. Grandes países periféricos seriam aqueles países não desenvolvidos, de grande população e de grande território contínuo, não-inóspito, razoavelmente passível de exploração econômica (Guimaraes, 1998, p. 9).

\section{Copyrights}

Copyright for this article is retained by the author, with first publication rights granted to the journal.

This is an open-access article distributed under the terms and conditions of the Creative Commons Attribution license (http://creativecommons.org/licenses/by/4.0/). 